
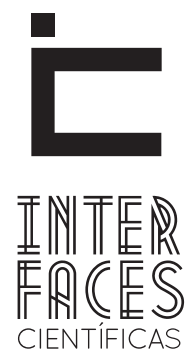

DIREITO

ISSN IMPRESSO 2316-3321

E - ISSN 2316-381X

DOI - 10.17564/2316-381X.2019v7n1p11-36

DOSSIÊ “30 ANOS DA CONSTITUIC̣̃̃O FEDERAL: GANHOS, PERDAS E DESAFIOS EM MATÉRIA DE DIREITOS HUMANOS”.

\title{
O ABORTO EM PAUTA NO PODER PÚBLICO BRASILEIRO: 30 ANOS DE BATALHAS CDESJFAVORÁVEIS À AUTONOMIA FEMININA
}

\author{
ABORTION ON THE AGENDA OF THE BRAZILIAN PUBLIC POWER: \\ 30 YEARS OF (UNJFAVORABLE BATTLES FOR FEMININE AUTONOMY \\ EL ABORTO EN PAUTA EN EL PODER PÚBLICO BRASILEÑO: \\ 30 AÑOS DE BATALLAS (DES) FAVORABLES A LA AUTONOMÍA FEMENINA
}

Salete Maria da Silva ${ }^{1}$
Enézio de Deus Silva Júnior ${ }^{3}$
Heron Santana Gordilho ${ }^{5}$
Sônia Jay Wright ${ }^{2}$

Ilzver Matos Oliveira ${ }^{4}$

\section{RESUMO}

0 presente artigo, desenvolvido com base em amplo material bibliográfico e audiovisual, tem como objetivo apresentar um panorama histórico-crítico das principais ações e debates públicos em torno da questão do aborto no Brasil. Em perspectiva feminista, destacamos, inicialmente, o momento da introdução deste tema na agenda política nacional, assim como sua rápida aparição na última Assembleia Nacional Cons- tituinte. Sequencialmente, e de maneira sintética, apresentamos o desenrolar das principais discussões na esfera pública federal - especialmente nos Poderes Legislativo, Executivo e Judiciário - nos últimos trinta anos. Refletimos, outrossim, sobre a natureza de alguns argumentos favoráveis e contrários à interrupção da gravidez, focando, particularmente, nos debates desenvolvidos na cúpula da justiça brasileira diante de 
uma ação judicial relacionada a casos de anencefalia. Por fim, e de forma sucinta, apresentamos e analisamos o contexto atual, destacando, especialmente, algumas contribuições de feministas brasileiras.

\section{ABSTRACT}

The present article, developed on base of a broad bibliographical and audiovisual material, has the objective of presenting an historical-critical panorama of the principal actions and public debates in regard of abortion in Brazil. In a feminist perspective, we initially highlight the moment this theme was introduced in the national political agenda, as well as its rapid appearance in the National Constituent Assembly. Sequentially, and in a synthetic manner, we present the unroll of the main discussion at the public federal sphere - especially Legislative, Executive and Judiciary powers, in the last thirty years. We also re-

\section{RESUMEN}

El presente artículo, desarrollado sobre la base de un amplio material bibliográfico y audiovisual, tiene como objetivo presentar un panorama histórico-crítico de las principales acciones y debates públicos en torno a la cuestión del aborto en Brasil. En perspectiva feminista, destacamos, inicialmente, el momento de la introducción de este tema en la agenda política nacional, así como su rápida aparición en la última Asamblea Nacional Constituyente. En la secuencia, y de manera sintética, presentamos el desarrollo de las principales discusiones en la esfera pública federal especialmente en los Poderes Legislativo, Ejecutivo y Judicial, en los últimos treinta años. Además, presentamos reflexiones sobre la naturaleza de algunos

\section{PALAVRAS-CHAVE}

Aborto. Poderes Públicos. Autonomia Feminina. Feminismo.

flect about the nature of some arguments in favor and against the interruption of pregnancy, focusing, specially, on the debates developed by the highest court of the Brazilian justice system regarding an anencephaly case. Finally, in a succinct matter, we present and analyze the present context, especially highlighting some contributions of Brazilian feminists.

\section{KEYWORDS}

Abortion. Public Powers. Feminine Autonomy. Feminism.

argumentos favorables y contrarios a la interrupción del embarazo, enfocándose particularmente en los debates desarrollados en la cúpula de la justicia brasileña ante una acción judicial relacionada con casos de anencefalia. Por fin, y de forma sucinta, presentamos y analizamos el contexto actual, destacando, especialmente, algunas contribuciones de feministas brasileñas

\section{PALABRAS CLAVE}

Aborto. Poderes Públicos. Autonomía femenina. Feminismo. 


\section{INTRODUÇ̄̃̃O}

A prática do aborto é crime no Brasil ${ }^{1}$, à exceção de três situações bem específicas, quais sejam: quando houver risco de morte para a mulher, em virtude da gravidez; quando a gravidez resultar de crime de estupro e quando o feto for diagnosticado como anencéfalo. As duas primeiras situações estão explícita e taxativamente previstas no Código Penal Brasileiro², já a última foi introduzida no país a partir de uma decisão do Supremo Tribunal Federal (STF) ${ }^{3}$, ocorrida em 2012.

A tipificação do crime de aborto em nosso país está contida em norma penal elaborada na década de 1940, isto é, quando sequer havia movimento feminista organizado no país ${ }^{4}$ ou Convenções internacionais relativas ao reconhecimento e à promoção dos direitos humanos das mulheres ${ }^{5}$. Já a possiblidade de abortamento em caso de fetos anencéfalos - autorizada pela mais alta corte de justiça brasileira -ocorreu em pleno século XXI, na vigência de uma Constituição Federal que prevê igualdade de direitos entre mulheres e homens e no contexto de uma sociedade onde há um dos mais destacados e aguerridos movi-

1 Em que pese o Brasil colônia não ter uma lei específica sobre o aborto, aplicavam-se, naquele período, as leis portuguesas e a visão da igreja católica sobre o tema, ou seja, era crime. No Brasil império, tanto na Constituição de 1824, como no Código Penal de 1830, o aborto foi mantido como crime em qualquer circunstância, mas com penas brandas. Com o advento da República e seu código penal de 1890 , a opção por criminalizar a prática abortiva foi repetida. Porém, foi somente no Código Penal de 1940 que se deu um tratamento mais específico sobre o tema e com penas bem mais severas.

2 Conforme o artigo 129 do Código Penal: "Não se pune o aborto praticado por médico: I - se não há outro meio de salvar a vida da gestante; II - se a gravidez resulta de estupro e o aborto é precedido de consentimento da gestante ou, quando incapaz, de seu representante legal”.

30 Supremo Tribunal Federal, na Arguição de Descumprimento de Preceito Fundamental de número 54 , julgou procedente o abortamento nos casos de anencefalia, reconhecendo o direito de escolha da gestante, que poderá optar em realizar o abortamento ou não, sendo necessário apenas laudo médico simples. Não há mais necessidade de autorização judicial. Basta apenas a autorização médica.

4 Nas primeiras décadas do século $X X$ floresceu um movimento feminista no Brasil, reunido na Federação Brasileira pelo Progresso Feminino (FBPF), com sucursais em diversos estados. Sua ênfase central era a conquista do voto feminino e sua representação no Parlamento e Executivos do País e dos estados brasileiros, o que aconteceu em 1932. Outra bandeira do movimento era a proteção às mães e a infância. A ditadura de Vargas, a partir de 1937, fez com que o movimento entrasse em recesso

5 Como a Convenção para a Eliminação de todas as Formas de Discriminação contra a Mulher, adotada pela ONU em 1979, e Convenção de Belém do Pará, adotada pela OEA em 1994. mentos feministas das Américas, que produz, inclusive, conhecimento científico sobre o tema.

No entanto, as exceções jurídicas acima referidas não atendem à totalidade das demandas feministas sobre o tema, pois não dão conta das necessidades das mulheres oriundas das mais distintas camadas sociais no Brasil, sobretudo as negras e pobres, que seguem abortando clandestinamente e expostas a altos riscos de infecção e mortalidade materna, além de serem alvo dos julgamentos social e judicial, posto que vistas como criminosas, quando deveriam ser titulares do direito de decidir livremente se querem ou não ter filhos e se desejam levar adiante uma gravidez (DINIZ, 2010; MIGUEL, 2012).

A luta dos movimentos feministas no Brasil, a exemplo de outros países do continente americano, tem sido pela descriminalização da prática abortiva ${ }^{6}$, além de sua legalização e oferta segura, gratuita e pública pelo Estado brasileiro, haja vista que, segundo alegam, cabe às mulheres e não ao Estado, decidir sobre suas vidas, seus corpos e suas escolhas (PINTO, 2003). Porém, a assunção pública desta demanda, assim como a construção de argumentos consistentes em defesa da mesma nem sempre foi fácil para os movimentos feministas brasileiros; afinal, o aborto tem sido, ao longo de anos, um tema tabu na esfera pública deste e de outros países.

Mesmo assim, a temática em comento deixou de ser objeto de interesse apenas de juristas e/ou de profissionais da saúde para ocupar as ações e as investigações científicas de pesquisadoras e ativistas feministas que têm se debruçado sobre o assunto, além de participarem ativamente do debate público, seja no Parlamento, no Executivo ou no Judiciário nacional, onde e quando a questão do aborto entra em cena, enfatizado a ideia dos direitos humanos das mulheres, e especialmente os direitos sexuais e reprodutivos ( $\mathrm{PI}$ MENTEL; VILELA, 2012; MIGUEL, 2012).

Diante deste quadro, concebemos o presente artigo, que foi desenvolvido com base em amplo material bibliográfico e audiovisual - como livros, textos 6 Pugna-se pela interrupção voluntária da gravidez até a décima segunda semana de gestação, conforme consta dos debates mais recentes realizados no âmbito do movimento e no próprio STF. 
científicos, normas jurídicas, anais da Constituinte, posicionamentos políticos e jurídicos oficiais, votos de ministros, notícias de jornais impressos, vídeos de audiências públicas, entrevistas diversas, dentre outros -, e tem como objetivo apresentar um panorama histórico e analítico-crítico das principais ações e debates públicos em torno da questão do aborto no Brasil.

Em perspectiva feminista, destacamos o momento da introdução do aborto na agenda política nacional, assim como sua rápida aparição na última Assembleia Nacional Constituinte. Sequencialmente, e de maneira sintética, apresentamos o desenrolar das discussões sobre a temática na esfera pública federal - especialmente nos Poderes Legislativo, Executivo e Judiciário - nos últimos trinta anos. Refletimos, outrossim, sobre a natureza de alguns argumentos favoráveis e contrários à interrupção da gravidez, focando, especialmente, nos debates desenvolvidos na cúpula da justiça brasileira, diante de uma ação judicial relacionada aos casos anencefalia. Por fim, e de forma sucinta, apresentamos e analisamos o contexto o atual, destacando, especialmente, algumas contribuições de feministas brasileiras.

\section{A INSERCC̄̃̃ DA TEMÁTICA NA AGENDA PÚBLICA NACIONAL}

A temática do aborto tem sido objeto de reflexões feministas desde o início da segunda onda do feminismo no Brasil, em plena ditadura militar. A premissa do "nosso corpo nos pertence" foi uma consigna recorrente ao longo daquele período, pois, segundo Sílvia Pimentel e Wilza Vilela (2012, p. 20), “a legalização do aborto sempre foi para o feminismo uma questão prioritária de direitos humanos das mulheres". Ademais, conforme destacam as mencionadas autoras: "Para as mulheres feministas, o direito ao aborto, a escolha de ter ou não ter filhos e o livre exercício da sexualidade eram, e ainda são, requisitos básicos e necessários de justiça social e para a consolidação das democracias" (PIMENTEL; VILELA, 2012, p. 20)

No entanto, a luta pública pela sua descriminalização, focando no Estado como interlocutor prio- ritário, só foi se desenvolver a partir da reabertura democrática, facilitada pelo contexto sociopolítico e pela criação de alguns organismos institucionais inseridos, inicialmente, nas estruturas de alguns governos locais e, posteriormente, no âmbito do governo federal ${ }^{7}$, todos voltados à promoção dos direitos das mulheres (SILVA, 2016).

Durante o período ditatorial, algumas pautas femininas mais próximas da temática em questão foram colocadas em discussão pelos movimentos de mulheres e feministas no Brasil, sendo apresentadas, estrategicamente, sob a rubrica de "saúde da mulher", tendo por objeto reflexões sobre sexualidade, planejamento familiar, métodos contraceptivos, maternidade, parto, dentre outros (TELES, 1999; PINTO, 2003; PIMENTEL; VILELA, 2012).

Inobstante as inúmeras dificuldades, no alvorecer da transição democrática, vozes femininas cristãs também começaram a discutir, no seio da igreja católica, o direito de decisão das mulheres frente à temática do aborto, conforme a circunstância ${ }^{8}$. De igual modo, no âmbito do movimento sindical, assim como em partidos de esquerda e algumas associações de classe, a exemplo da Federação Brasileira de Ginecologia e Obstetrícia (FEBRASGO), o debate também começou a ser desenvolvido, mas não sem resistência por parte daqueles que consideravam tal luta uma questão menor ou mesmo secundária, frente aos problemas mais gerais da nação brasileira (PIMENTEL; VILELA, 2012).

\section{A TEMÁTICA DO ABORTO NA CONSTITUINTE DE $87 / 88$}

Com o advento da democracia, os direitos das mulheres adentraram paulatinamente no âmbito do Estado, o que favoreceu as primeiras discussões sobre a 7 A exemplo dos Conselhos Estaduais da Condição Feminina, criados em 1983 em São Paulo e Minas Gerais e do Conselho Nacional dos Direitos da Mulher, instituído em 1985

80 movimento Católicas pelo Direito de Decidir foi criado na década de 1970 nos Estados Unidos e no Brasil em 1993. A ONG dispõe-se a debater assuntos silenciados pela Igreja Católica, como a autonomia das mulheres sobre seus corpos e a diversidade sexual. 
temática do aborto como um problema de saúde pública e de responsabilidade dos poderes constituídos frente à questão (TELES, 1999). Dentre as discussões, merece destaque a aparição deste tema no âmbito da Constituinte, por meio da Emenda Popular de número 65, que fora subscrita por 33.338 pessoas e teve como proponentes as seguintes entidades: Coletivo Feminista Sexualidade e Saúde (SP), União de Mulheres de São Paulo (SP) e Grupo de Saúde Nós Mulheres (RJ), sendo apoiada por mais 19 entidades (SILVA, 2016).

A defesa pública desta emenda coube à feminista Maria Amélia de Almeida Teles que, há exatos trinta anos, subiu à tribuna do Parlamento Nacional, em pleno processo de elaboração da atual Constituição Federal, para colocar em discussão a temática do aborto, em pleno seio da Assembleia Nacional Constituinte (ANC), da qual as mulheres, por meio do grupo de pressão denominado lobby do batom ${ }^{9}$, participaram ativa e corajosamente (SILVA, 2016).

Na ocasião, Amelinha, como é conhecida esta veterana feminista brasileira que hoje se encontra com 74 anos de idade, apresentou a referida Emenda, cujo conteúdo, em termos de técnica legislativa, conforme Silva (2016, p. 273), dizia o seguinte:

Inclua, onde couber, na Seção I (Da Saúde), do Capítulo II (Da Seguridade Social), do Título IX (Da Ordem Social), os seguintes dispositivos: Art. - Compete ao Poder Público prestar assistência integral à saúde da mulher, nas diferentes fases de sua vida, garantir a homens e mulheres o direito de determinar livremente o número de filhos, sendo vedada a adoção de qualquer prática coercitiva pelo Poder Público e por entidades privadas, assegurar acesso à educação, informação e aos métodos adequados à regulamentação de fertilidade, respeitadas as opções individuais. Art. - A mulher tem o direito de conceber, evitar a concepção ou interromper a gravidez indesejada, até 90 (noventa) dias de seu início. $\S 1^{\circ}$ - Compete ao Estado garantir este direito através da prestação de assistência integral às mulheres na rede de saúde pública. $\S 2^{\circ}$ - Serão respeitadas as convicções éticas, religiosas individuais.

9 Grupo de pressão composto por representantes dos movimentos feministas e de mulheres dos mais variados estados brasileiros, deputadas constituintes e representantes do Conselho Nacional dos Direitos das Mulheres.
Em seu pronunciamento, que deve ser lembrado como um momento histórico na luta pela descriminalização do aborto no país, Amelinha tratou deste assunto não apenas como mais um direito da parcela feminina da sociedade, mas como uma questão de saúde, destacando o crescente número de mortes de mulheres decorrentes da realização clandestina de tal prática. Sua intervenção, que está detalhada no livro "A Carta que Elas Escreveram: as mulheres na Constituinte de 1987/88"10, animou importantes debates acerca da temática em apreço, haja vista que causou polêmica não somente entre as mulheres participantes do lobby referido, mas entre as deputadas e deputados constituintes que, em sua maioria, resistiam em tratar do tema naquele momento histórico e, sobretudo, em sede constitucional.

Em face do exposto e, levando em consideração o contexto da época, as mulheres organizadas de então optaram por não tensionar a Assembleia Constituinte em torno da referida discussão, pois havia o temor da perda de aliadas/os entre as e os parlamentares, ou a retirada de apoio em face de demandas já consensuadas em outras comissões temáticas, em torno de outros direitos igualmente relevantes para a ampliação da cidadania feminina. Assim, o debate sobre o aborto, embora apresentado de maneira ousada e corajosa no âmbito da Constituinte, não obteve maior fôlego, haja vista as razões acima aduzidas (SILVA, 2016).

A temática do aborto também foi tratada, ainda que in passant, na Subcomissão dos Direitos e Garantias Individuais e na Subcomissão da Família, do Menor e do Idoso da ANC de 1987/88, mas sem grandes progressos. Nesta última, de acordo com Silva (2016), Eleonora Menicucci, em pronunciamento feito no dia 29/4/1987, defendeu o direito das mulheres à informação idônea sobre seu próprio corpo, bem como o direito de ter acesso gratuito a todos os métodos contraceptivos, vez que, segundo a mesma, isto deveria ser política pública do Estado.

10 Este livro é resultante da tese de doutorado de Salete Maria da Silva, aprovada com distinção em 2012 no Programa de Estudos Interdisciplinares sobre Mulheres, Gênero e Feminismo, da Universidade Federal da Bahia-UFBA, sob a orientação da doutora Ana Alice Alcântara Costa. 
Segundo Silva (2016, p. 257), as deputadas constituintes Abigail Feitosa e Benedita da Silva também se reportaram ao tema durante os debates nas audiências públicas, merecendo destaque as seguintes passagens de suas intervenções:

\begin{abstract}
A SRA CONSTITUINTE ABIGAIL FEITOSA - [] Eu, por exemplo, acho que essa questão que o companheiro colocou, de que mesmo estuprada ela deve aceitar a gravidez, tem que ser vista direito. Nós não podemos ser mais realistas do que o rei. Imaginem aqui a filha de qualquer um de nós estuprada por uma pessoa que ela não sabe nem quem é, e ela engravida. Ela vai carregar a vida inteira. Não é a questão de um crime contra o outro, mas ela vai ter o direito de decidir. Nós não podemos culpar essa mulher, ela ter que carregar no ventre um fitho que não sabe nem de quem é, de uma violência que sofreu. Acho que estamos indo longe demais na coisa. ${ }^{11}$

A Sra. CONSTITUINTE BENEDITA DA SILVA - () Não podemos deixar de reconhecer que quando estamos falando da vida, uma vida que está no útero de uma pessoa, temos de entender também todo o complexo que envolve essa pessoa. E a partir daí, então, vamos poder escrever com todas as letras tudo aquilo. E se, no final de todas as discussões entre nós, não chegarmos a um denominador comum, é muito importante que determinados temas levemos para o grande debate, o debate que se dará no seio da sociedade. Pode ser com perdas ou com ganhos, mas que não fechemos totalmente as portas, garantindo pelo menos, dada a situação que hoje já podemos visualizar, que não haja um retrocesso. ${ }^{12}$
\end{abstract}

As manifestações das referidas Parlamentares constituíam uma exceção no contexto da Constituinte, já que a maioria dos deputados quando não se manifestavam abertamente contrários ao aborto, usavam do subterfúgio de que esta não era matéria de índole constitucional (SILVA, 2016). De toda sorte, "na Assembleia Nacional Constituinte, os movimentos feministas e seus aliados tiveram sucesso ao barrar a tentativa da Igreja Católica de incluir, no artigo $5^{\circ}$ da Constituição Federal de 1988, o princípio do direito à vida desde a concepção" (MIGUEL; BIROLI; MARIANO, 2017, p. 236).

11 Discurso na íntegra disponível em “Diário da Assembleia Nacional Constituinte" de 20/5/1987 (p. 225-226).

12 Discurso na íntegra disponível em "Diário da Assembleia Nacional Constituinte" de 21/5/1987 (p. 212, $1^{\text {a }}$ coluna).

\section{PRINCIPAIS AÇÕES E DEBATES NO PODER PÚ- BLICO FEDERAL}

\subsection{O ABORTO NO PARLAMENTO NACIONAL}

Nos trinta anos que se seguiram à Assembleia Constituinte, o tema do aborto foi ganhando destaque no debate público brasileiro, apesar das inúmeras tentativas de escamoteá-lo, sobretudo por parte do Parlamento federal que, em tese, deveria se constituir como uma Casa de amplas e qualificadas discussões sobre as questões que afetam a sociedade brasileira como um todo e as mulheres em particular, haja vista se tratar de mais da metade da população do país e do próprio eleitorado nacional.

Todavia, por se tratar de um dos poderes onde a presença masculina ainda se faz majoritária e cuja composição se caracteriza por um flagrante conservadorismo da maioria dos seus membros, o teor das discussões nem sempre correspondem às demandas femininas, haja vista as inúmeras proposições legislativas que se constituem em verdadeiras ameaças aos direitos já conquistados pelas mulheres brasileiras, sobretudo em matéria de saúde e direitos sexuais e reprodutivos (MIGUEL; BIROLI; MARIANO, 2017).

A título de exemplo, somente no ano de $2015^{13}$, quando a Câmara dos Deputados esteve sob a presidência do deputado Eduardo Cunha, parlamentar vinculado a grupos religiosos refratários aos debates sobre o tema, diversos projetos destinados a retirar direitos sexuais e reprodutivos das mulheres, ou a dificultar o acesso delas ao aborto legal, foram desengavetados e/ ou apresentados na mencionada Casa Legislativa, sendo que as proposições legislativas que visam ampliar os direitos das mulheres sobre esta ou outras matérias foram mantidos arquivados ou publicamente desqualificados (BIROLI, 2016; OLIVEIRA, 2017).

13 Neste mesmo ano, visando resistir à ofensiva conservadora que ganhou fôlego com o resgate do PL 5069/2013 e protestar contra a ocorrência de duas mortes decorrentes de abortos clandestinos ocorridas no Rio de Janeiro no ano anterior, feministas brasileiras articularam manifestações pelo país inteiro, com palavras de ordem como "Fora Cunha!" e "Tirem seus rosários dos nossos ovários". Tais manifestações ficaram conhecidas como "Primavera Feminista" e foram as maiores já ocorridas nos Brasil sobre a temática do aborto. 
Nos quadros a seguir, registramos alguns dos projetos de leis favoráveis e contrários aos direitos das mulheres, apresentados ao longo das três últimas décadas:

Quadro 1 - Projetos de Lei (PL) que restringem ou ameaçam direitos sexuais e reprodutivos das mulheres

\begin{tabular}{|c|c|c|}
\hline $\begin{array}{l}\text { Número do } \\
\text { projeto }\end{array}$ & Proponente & Natureza \\
\hline $\begin{array}{c}P L \\
5069 / 2013\end{array}$ & $\begin{array}{l}\text { Eduardo } \\
\text { Cunha } \\
\text { (PMDB-RJ) }\end{array}$ & $\begin{array}{l}\text { Visa aumentar pena } \\
\text { para mulheres que } \\
\text { pratiquem aborto e pro- } \\
\text { fissionais da saúde que } \\
\text { lhes dê assistência'1. }\end{array}$ \\
\hline $\begin{array}{c}P L \\
6033 / 2013\end{array}$ & $\begin{array}{l}\text { Eduardo } \\
\text { Cunha } \\
\text { (PMDB-RJ) }\end{array}$ & $\begin{array}{l}\text { Visa revogar a Lei } \\
\text { 12845/2013, que trata } \\
\text { do atendimento às } \\
\text { vítimas de violência } \\
\text { sexual. }\end{array}$ \\
\hline $\begin{array}{c}P L \\
1545 / 2011\end{array}$ & $\begin{array}{l}\text { Eduardo } \\
\text { Cunha } \\
\text { (PMDB-RJ) }\end{array}$ & $\begin{array}{l}\text { Visa aumentar a pena } \\
\text { para médicos que } \\
\text { realizem aborto fora } \\
\text { dos casos legais. }\end{array}$ \\
\hline $\begin{array}{c}P L \\
3748 / 2008\end{array}$ & $\begin{array}{l}\text { Suely Vidi- } \\
\text { gal (PDT-ES) }\end{array}$ & $\begin{array}{c}\text { Visa autorizar o Poder } \\
\text { Executivo a conceder } \\
\text { pensão à mãe que man- } \\
\text { tenha a criança nascida } \\
\text { de gravidez decorrente } \\
\text { de estupro. }{ }^{3}\end{array}$ \\
\hline PL 313/2007 & $\begin{array}{l}\text { Maurício } \\
\text { Trindade } \\
\text { (PR/BA) }\end{array}$ & $\begin{array}{l}\text { Visa restringir acesso a } \\
\text { pílula do dia seguinte } 4\end{array}$ \\
\hline PL 478/2007 & $\begin{array}{l}\text { Luiz Bassu- } \\
\text { ma (ex-PT/ } \\
\text { BA) Miguel } \\
\text { Martini } \\
\text { (PHS-)MG_ }\end{array}$ & $\begin{array}{l}\text { Visa instituir o Estatuto } \\
\text { do Nascituro e proibir } \\
\text { o aborto em qualquer } \\
\text { circunstância no país. }\end{array}$ \\
\hline
\end{tabular}

\begin{tabular}{|c|c|c|}
\hline $\begin{array}{l}\text { Número do } \\
\text { projeto }\end{array}$ & Proponente & Natureza \\
\hline $\begin{array}{c}P L \\
7443 / 2006\end{array}$ & $\begin{array}{l}\text { Eduardo } \\
\text { Cunha } \\
\text { (PMDB-RJ) }\end{array}$ & $\begin{array}{l}\text { Visa transformar o } \\
\text { aborto em crime he- } \\
\text { diondo }\end{array}$ \\
\hline $\begin{array}{c}P L \\
5166 / 2005\end{array}$ & $\begin{array}{l}\text { Hidekazu } \\
\text { Takayama } \\
\text { (PSC/PR), }\end{array}$ & $\begin{array}{l}\text { Visa impedir realização } \\
\text { de aborto em caso de } \\
\text { má-formação do feto. }\end{array}$ \\
\hline $\begin{array}{c}P L \\
5364 / 2005\end{array}$ & $\begin{array}{c}\text { Luiz Bassu- } \\
\text { ma (ex-PT) }\end{array}$ & $\begin{array}{c}\text { Visa autorizar a } \\
\text { revogação de todas as } \\
\text { normas que preveem } \\
\text { aborto no Brasil } \\
\end{array}$ \\
\hline $\begin{array}{c}\mathrm{PL} \\
1459 / 2003\end{array}$ & $\begin{array}{l}\text { Severino } \\
\text { Cavalcanti } \\
\text { (PP/PE), }\end{array}$ & $\begin{array}{c}\text { Visa impedir a reali- } \\
\text { zação de aborto em } \\
\text { caso de má-formação } \\
\text { do feto }\end{array}$ \\
\hline $\begin{array}{c}P L \\
7235 / 2002\end{array}$ & $\begin{array}{l}\text { Severino } \\
\text { Cavalcante } \\
\text { (PPB-PE) }\end{array}$ & $\begin{array}{c}\text { Visa revogar a autori- } \\
\text { zação do aborto em ca- } \\
\text { sos de não haver outro } \\
\text { meio de salvar a vida } \\
\text { da gestante e em caso } \\
\text { de gravidez resultante } \\
\text { de estupro. }\end{array}$ \\
\hline $\begin{array}{c}\mathrm{PL} \\
4703 / 1998\end{array}$ & $\begin{array}{c}\text { de Francisco } \\
\text { Silva - (PPB/ } \\
\text { RJ) }\end{array}$ & $\begin{array}{l}\text { Visa transformar } \\
\text { o aborto em crime } \\
\text { hediondo }\end{array}$ \\
\hline $\begin{array}{c}\mathrm{PL} \\
1035 / 1991\end{array}$ & $\begin{array}{c}\text { Ex-senador } \\
\text { Jamil Ha- } \\
\text { ddad (PSB/ } \\
\text { RJ), } \\
\end{array}$ & $\begin{array}{c}\text { Tipifica e criminaliza o } \\
\text { aborto como crime de } \\
\text { tortura }\end{array}$ \\
\hline $\begin{array}{c}P L \\
2423 / 1989\end{array}$ & $\begin{array}{c}\text { Ex-senador } \\
\text { Jamil Ha- } \\
\text { ddad (PSB/ } \\
\text { RJ) }\end{array}$ & $\begin{array}{c}\text { Tipifica e criminaliza o } \\
\text { aborto como crime de } \\
\text { tortura }\end{array}$ \\
\hline
\end{tabular}

Fonte: elaboração da autoria deste artigo com base em dados da Câmara dos Deputados 
Quadro 2 - Projetos de Lei que visam ampliar direitos sexuais e reprodutivos das mulheres

\begin{tabular}{|c|c|c|}
\hline $\begin{array}{l}\text { Número do } \\
\text { projeto }\end{array}$ & Proponente & Natureza \\
\hline $\begin{array}{c}\mathrm{PL} \\
7633 / 2014\end{array}$ & $\begin{array}{l}\text { Jean Wyllys } \\
\text { (PSOL/RJ) }\end{array}$ & $\begin{array}{l}\text { Visa regulamentar e } \\
\text { ampliar os direitos das } \\
\text { mulheres que abortarem } \\
\text { na rede pública, em casos } \\
\text { já previstos em lei. Proíbe } \\
\text { que a rede de saúde pú- } \\
\text { blica recuse ou retarde } \\
\text { o atendimento oportuno } \\
\text { e eficaz à mulher em } \\
\text { qualquer fase do ciclo } \\
\text { gravídico-puerperal ou em } \\
\text { abortamento, indepen- } \\
\text { dente de necessidade de } \\
\text { urgência da assistência à } \\
\text { mulher nesses casos }\end{array}$ \\
\hline $\begin{array}{c}P L \\
60 / 1999\end{array}$ & $\begin{array}{l}\text { Iara Bernar- } \\
\text { di - PT/SP }\end{array}$ & $\begin{array}{l}\text { Visa regulamentar o } \\
\text { atendimento obrigatório } \\
\text { e integral de pessoas } \\
\text { em situação de violência } \\
\text { sexual }{ }^{7} \text {. }\end{array}$ \\
\hline $\begin{array}{c}\mathrm{PL} \\
176 / 1995\end{array}$ & $\begin{array}{l}\text { José Genoí- } \\
\text { no (PT/SP) }\end{array}$ & $\begin{array}{l}\text { Visa legalizar o aborto } \\
\text { sem restrições, até } 90 \\
\text { dias, e determina que } \\
\text { para a realização do abor- } \\
\text { to bastará a reivindicação } \\
\text { da gestante. }\end{array}$ \\
\hline $\begin{array}{c}P L \\
1135 / 91\end{array}$ & $\begin{array}{l}\text { Eduardo } \\
\text { Jorge } \\
\text { (quando } \\
\text { era do PT) } \\
\text { e Sandra } \\
\text { Starling } \\
\text { (então PT) }\end{array}$ & $\begin{array}{l}\text { Visa a descriminalização } \\
\text { do aborto no Brasil. }\end{array}$ \\
\hline
\end{tabular}

Fonte: elaboração da autoria deste artigo com base em dados da Câmara dos Deputados
Pelo que se pode depreender dos quadros acima expostos, notadamente do primeiro, as proposições legislativas apresentadas e fortalecidas, sobretudo por parlamentares homens, visam, em sua maioria, restringir os direitos das mulheres, especialmente os direitos sexuais e reprodutivos. Assim, não resta dúvida de que a atuação de muitos parlamentares brasileiros não vem se dando em consonância com as demandas formuladas pelos movimentos feministas e de mulheres, sobretudo quando se trata de ampliação da cidadania feminina. Afinal, muitos projetos de lei, a exemplo dos acima mencionados, representam um verdadeiro retrocesso com relação ao aprofundamento da autonomia das mulheres e ao próprio ordenamento jurídico vigente no país, haja vista que, se uma mulher for submetida à violência sexual atualmente e, em face disto, vier a engravidar, ela pode, legalmente, solicitar a interrupção da gestação (ROCHA, 2006).

Todavia, se o Estatuto do Nascituro vier a ser aprovado, por exemplo, o aborto em caso de estupro passará a ser ilegal, ou seja, retrocederemos pelo menos em 70 anos, já que esta possibilidade existe desde 1940, com o advento do Código Penal. Destarte, como bem destacou a professora Sonia Wright, em debate realizado sobre o tema14, "trata-se de uma proposta que impõe um duro golpe no avanço dos direitos das mulheres, sendo inclusive incompatível com a própria ideia de Estado Democrático de Direito e de dignidade humana, constante da Lei Maior."

Além do exposto, o Estatuto do Nascituro ainda pune quem fizer, publicamente, "apologia do aborto ou de quem o praticou, ou incitar publicamente a sua prática". Ou seja, caso seja aprovado, estarão sob ameaça de processo e prisão não somente as mulheres que necessitem abortar, mas as próprias pesquisadoras e ativistas dos movimentos sociais que atuam em prol dos direitos humanos das mulheres.

Para além dos projetos de lei, de iniciativa das e dos parlamentares há, atualmente, no Senado

14 Debate realizado em março de 2015, na Universidade Federal da Bahia, sob o título de "Nem onda conservadora, nem política da tesoura", organizado por docentes e discentes do Bacharelado em Estudos de Gênero e Diversidade, e com participação efetiva do coletivo Jusfemina, posteriormente transformado em grupo de pesquisa. 
Federal a Sugestão de no 15 de 2014, de iniciativa popular15, cujo objetivo é regular a interrupção voluntária da gravidez dentro das doze primeiras semanas de gestação, pelo sistema único de saúde. Esta iniciativa já oportunizou a realização de cinco audiências públicas sob o comando da Comissão de Direitos Humanos do Senado. As audiências públicas realizadas ao longo do ano de 2015, evidenciaram a forte polarização entre os grupos contrários e favoráveis à descriminalização do aborto (OLIVEIRA, 2017). Representantes de diversos movimentos e instituições sociais (religiosas, científicas ou de classe) apresentaram suas posições com vistas a influenciar a atuação dos parlamentares.

$\mathrm{Na}$ audiência pública ocorrida em 6 de agosto de 2015, a pesquisadora Débora Diniz, docente Faculdade de Direito da Universidade de Brasília e vinculada ao Instituto de Bioética, Direitos Humanos e Gênero, da referida instituição, apresentou dados de uma pesquisa nacional sobre aborto coordenada por ela no ano de 2010. Segundo a mesma, os resultados apontam que uma em cada cinco mulheres brasileiras já realizou pelo menos um aborto até os 40 anos. $E$, conforme a docente, "não sabemos quantas mulheres abortam no país, mas entre 18 e 39 anos, 7,4 milhões já abortaram em algum momento da vida" (AGÊNCIA SENADO, 2015).

Neste encontro, um padre de nome Paulo Ricardo afirmou que instituições estrangeiras, como a Fundação Ford e a MacArthur, manipulam estudiosos brasileiros "como forma de impor ao Brasil uma diminuição do ritmo de crescimento populacional”. Segundo este reverendo, as fundações mencionadas investiram recursos humanos e financeiros para que houvesse ampla liberação do aborto no Hemisfério Norte, desde as décadas de 1950 e 1960. Mas agora, segundo o mes-

\footnotetext{
15 Esta sugestão foi apresentada mediante subscrição de 20 mil pessoas e visa permitir a interrupção voluntária da gravidez ainda no primeiro trimestre, por meio do Sistema Único de Saúde (SUS). Trata-se uma proposição enviada através do Portal e-Cidadania do Senado Federal, cujos encaminhamentos estão regulados pelo Ato da Mesa $n^{0} 3$, de 2011 e requerem o apoio de, no mínimo, 20 mil assinaturas, constituindo-se em importantes peças para a atuação parlamentar de todos os senadores. Seu acompanhamento pode se dar por meio do seguinte endereço eletrônico: https:// www25.senado.leg.br/web/atividade/materias/-/materia/119431
}

mo, chegou a vez de investir em pesquisas antropológicas e sociológicas em países como o Brasil a fim de que o aborto seja legalizado; ele fecha seu argumento, assim dizendo:

Basta ler os relatórios das fundações internacionais, não estou citando catecismo, Bíblia, estou citando documentos públicos e notórios, e não me venham com esse nhem-nhem-nhem de laicidade do Estado porque isso é maracutaia ${ }^{16}$.

\subsection{O ABORTO NO PODER EXECUTIVO NACIONAL}

Se no âmbito do Legislativo o debate sobre o aborto vem ganhando espaço, apesar do flagrante descompromisso da maioria dos parlamentares com a ampliação da cidadania feminina, no Executivo, ao longo dos últimos 30 anos, não houve grandes avanços no tratamento da temática. Na verdade, dentre os cinco presidentes e uma presidenta que o Brasil já teve desde o advento da atual Constituição ${ }^{17}$, nenhum/a tratou da temática do aborto de forma explícita, segura, corajosa e republicana, nem em suas campanhas eleitorais, o que fortalece, ainda que de forma indireta, as forças conservadoras e reacionárias da sociedade e do próprio Parlamento que se opõem às demandas das mulheres com relação a este tema e suas lutas pró escolha.

E por falar em campanha eleitoral, vale pontuar que, desde o pós-Constituinte, este tema tem aparecido nas disputas sucessórias de âmbito federal, sobretudo para cargos majoritários, como estratégia de manipulação do eleitorado mais conservador ou como forma de constranger ou chantagear as candidaturas progressistas que, diante deste expediente, tendem a se posicionar de forma desfavorável às demandas feministas sobre o tema. Tal estratégia foi utilizada já na campanha eleitoral de 1989, quando o Luís Inácio Lula da Silva disputava, pela primeira vez, à presidência do país.

16 A íntegra da fala do religioso pode ser visualizada em https://www.youtube.com/watch?v=gaaJQVZSGss

17 Para relembrar, desde a retomada das eleições diretas, foram presidentes: Fernando Collor, Itamar Franco, Fernando Henrique Cardoso (dois mandatos), Luís Inácio Lula da Silva (dois mandatos), Dilma Roussef (dois mandatos, um deles interrompido por impeachment) e Michel Temer. 
Na ocasião, e já na reta final do mencionado período, foi exibido, no horário eleitoral do candidato Fernando Collor de Mello, um vídeo onde uma ex-namorada do petista apresentava um "depoimento bombástico", alegando que o metalúrgico a abandonou na gravidez, na década de 1970, após lhe propor que fizesse um aborto. Nos pleitos que se seguiram, o assunto esteve menos presente, porém, nas eleições dos anos 2000, mais especificamente em 2010 e 2014, a temática do aborto foi invocada com bastante frequência (ALMEIDA; BANDEIRA, 2013).

A título de exemplo, vale lembrar que, em outubro de 2010, milhares de panfletos que associavam a candidata Dilma Roussef à defesa do aborto foram apreendidos pela polícia federal ${ }^{18}$. Tais panfletos, segundo o proprietário da gráfica que os produzia, foram encomendados pela Diocese de Guarulhos. Em resposta ao incidente e por meio de um texto intitulado "Mensagem da Dilma"19 público que não proporia qualquer medida relacionada à descriminalização ou legalização do aborto, caso eleita, conforme consta do conteúdo do texto, cujos fragmentos destacamos o seguinte:

1. Defendo a convivência entre as diferentes religiões e a liberdade religiosa, assegurada pela Constituição Federal; 2. Sou pessoalmente contra o aborto e defendo a manutenção da legislação atual sobre o assunto; 3. Eleita presidente da República, não tomarei a iniciativa de propor alterações de pontos que tratem da legislação do aborto e de outros temas concernentes à família e à livre expressão de qualquer religião no País.

Neste período, o candidato José Serra se manifestou veementemente contrário ao aborto, insinuando que a candidata do Partido dos Trabalhadores (PT) tinha "duas caras" pois, segundo ele, não assumia sua verdadeira posição sobre o tema em apreço. Dias depois, circularam boatos e notícias referentes a um suposto aborto realizado pela professora Mônica Ser-

18 Para maiores detalhes, ler a matéria de 0 Globo. Disponível em http:// g1.globo.com/especiais/eleicoes-2010/noticia/2010/10/pf-apreende-panfletos-contra-dilma-em-grafica-de-sao-paulo.html

19 Texto na íntegra disponível em https://noticias.uol.com.br/ultimas-noticias/reuters/2010/10/15/texto-carta-de-dilma-sobre-aborto-e-liberdade-religiosa.jhtm ra, esposa do candidato tucano e divulgado por uma ex-aluna da mesma ${ }^{20}$

No mesmo pleito, a candidata Mariana Silva também acusou Dilma Roussef de mudar o discurso para ganhar as eleições. E, por seu turno, se disse ser pessoalmente contrária ao aborto, mas defendeu que o tema fosse objeto de um plebiscito de caráter nacional.

Na campanha de 2014, o tema do aborto também veio à tona, mas não com o mesmo ímpeto do pleito anterior. Nesta ocasião, os candidatos Eduardo Jorge ${ }^{21}$, Mauro lasi e José Maria foram os únicos presidenciáveis do sexo masculino a se manifestarem, de forma clara e inequívoca, a favor da legalização do aborto, assim como a candidata Luciana Genro, que sempre tratou de forma aberta e explícita desta temática. Dilma Roussef e Marina Silva mantiveram as posições da campanha anterior, quais sejam, contrárias à legalização, assim como os candidatos Aécio Neves, Pastor Everaldo, Levy Fidelix e Eymael. No quadro abaixo, elaborado com base em matéria do Uol, publicada em 14/07/2014²2, exibimos uma síntese da posição de cada presidenciável sobre o aborto, naquele contexto:

Quadro 3 - Posição de presidenciáveis sobre o tema do aborto em 2014

\begin{tabular}{|c|c|}
\hline Presidenciável & Posição sobre o aborto \\
\hline Aécio Neves (PSDB) & $\begin{array}{c}\text { Contra a descriminalização } \\
\text { e favorável à manutenção da } \\
\text { legislação atual. }\end{array}$ \\
\hline Dilma Rousseff (PT) & $\begin{array}{c}\text { Contra a descriminalização } \\
\text { e favorável à manutenção da } \\
\text { legislação atual. }\end{array}$ \\
\hline
\end{tabular}

20 Disponível em https://www.conversaafiada.com.br/brasil/2010/10/16/ mulher-de-serra-abortou-diz-aluna-ele-passou-trator-por-cima-da-mulher 21 Quando fora deputado federal apresentou um projeto de lei em prol da descriminalização do aborto, mencionada no Quadro 2 deste texto.

22 Conferir a matéria intitulada " 0 que pensam os candidatos sobre aborto, maconha e religião". Disponível em https://eleicoes.uol.com.br/2014/ noticias/2014/07/14/veja-o-que-pensam-candidatos-a-presidencia-sobre-aborto-maconha-e-religiao.htm 


\begin{tabular}{|c|c|}
\hline Marina Silva (PSB) & $\begin{array}{l}\text { Contra a descriminalização e } \\
\text { favorável à realização de um } \\
\text { plebiscito. }\end{array}$ \\
\hline Eduardo Jorge (PV) & $\begin{array}{l}\text { Favorável à descriminaliza- } \\
\text { ção com estabelecimento } \\
\text { de regras e limites de idade } \\
\text { gestacional. }\end{array}$ \\
\hline Eymael (PSDC) & $\begin{array}{l}\text { Contra a descriminalização e } \\
\text { favorável à manutenção da le- } \\
\text { gislação atual, fundamenta sua } \\
\text { posição em orientação cristã. }\end{array}$ \\
\hline José Maria (PSTU) & Favorável à descriminalização. \\
\hline Levy Fidelix (PRTB) & $\begin{array}{c}\text { Contra a descriminalização } \\
\text { e favorável à manutenção da } \\
\text { legislação atual, exceto em } \\
\text { caso de estupro, pois acredita } \\
\text { que nesta situação a interrup- } \\
\text { ção da gravidez não deveria } \\
\text { ser autorizada. }\end{array}$ \\
\hline $\begin{array}{l}\text { Luciana Genro } \\
\text { (PSOL) }\end{array}$ & $\begin{array}{l}\text { Favorável à descriminalização, } \\
\text { contra a hipocrisia e por um } \\
\text { debate franco sobre contra- } \\
\text { cepção e maternidade. }\end{array}$ \\
\hline Mauro lasi (PCB) & $\begin{array}{l}\text { Favorável à descriminaliza- } \\
\text { ção, entende que se trata de } \\
\text { um direito da mulher e deve } \\
\text { ser realizado na rede pública } \\
\text { de saúde. }\end{array}$ \\
\hline $\begin{array}{l}\text { Pastor Everaldo } \\
\text { (PSC) }\end{array}$ & $\begin{array}{l}\text { Contra a descriminalização, } \\
\text { a favor da vida a partir da } \\
\text { concepção, pela manutenção } \\
\text { da legislação atual. }\end{array}$ \\
\hline
\end{tabular}

Fonte: elaboração da autoria deste artigo com base em dados do Universo Online, Uol em 2014.

Conforme demonstra o quadro acima, o debate em torno do aborto nas campanhas eleitorais não tem contribuído para um maior avanço das reflexões e proposições políticas sobre o assunto no Brasil pois, como afirmou a líder da ONG Católicas pelo Direito de Decidir, Maria José Rosado Nunes, em setembro de 2010, "o tema virou moeda de troca" em períodos eleitorais ${ }^{23}$

Ademais disto, ao longo das últimas três décadas, nenhuma das figuras públicas que ocuparam o Palácio do Planalto na condição de chefe do país assumiu posições claras e proativas acerca da questão do aborto no Brasil. Ao contrário: nem mesmo presidentes oriundos de partidos de esquerda e apoiados por movimentos feministas que lutam em prol desta causa, como Lula e Dilma, jamais adotaram ações concretas e progressistas diante do tema, haja vista suas posturas conciliatórias, ambíguas e, sobretudo, tranquilizadoras de suas bases de apoio - constituídas também por líderes religiosos e membros de outros seguimentos igualmente contrários à prática do aborto.

Convém pontuar, ainda com relação a esta pauta no âmbito do Poder Executivo, que a adoção de medidas burocráticas, necessárias ao fiel cumprimento da lei penal em vigor, tais como portarias e normas técnicas, não devem ser tomadas como atitudes inovadoras e efetivamente favoráveis às demandas das mulheres sobre o assunto; afinal, são exigências da própria legislação que requer a produção de atos administrativos capazes de possibilitar a materialização dos conteúdos normativos.

Destarte, a assinatura de uma norma técnica, pelo então Ministro da Saúde do governo de Fernando Henrique Cardoso (FHC), José Serra, em 1998, com vistas à regulamentar os procedimentos da realização do aborto legal pelo Sistema único de Saúde (SUS), não deve ser vista como uma postura favorável às demandas das mulheres por parte destes políticos, pois, em sucessivas campanhas eleitorais, o próprio Serra se colocou contrário à descriminalização do aborto. No entanto, deve ser considerado como uma batalha cujo resultado foi parcialmente favorável aos movimentos feministas.

Cabe destacar, todavia, que no último ano do go-

23 Conferir a matéria intitulada " 0 aborto e as eleições presidenciais", publicada por Celso Marcondes em 30/09/2010 ás 18h46. Disponível em: http://webcache.googleusercontent.com/search?q=cache:pPhF4RU DIIIJ:https://www.cartacapital.com.br/politica/o-aborto-e-as-eleicoes-presidenciais\&hl=pt-BR\&gl=br\&strip=1\&vwsrc=0 
verno FHC, o Programa Nacional de Direitos Humanos - 2 defendia o alargamento das permissões para a prática do aborto. Ademais disto, a própria primeira dama, doutora Ruth Cardoso (SANTOS, 1997), sempre se pronunciou favoravelmente à ampliação da cidadania feminina quanto a este aspecto; o que, mais uma vez, não deve ser lido como um apoio amplo e irrestrito do referido governo às demandas das mulheres sobre o tema tratado.

Do mesmo modo, a assinatura de norma técnica pelo ministro da Saúde, o médico Humberto Costa, no primeiro mandato de Lula, ampliando o teor da norma outrora assinada por José Serra, desta feita dispensando a exigência de boletim de ocorrência para aborto no SUS em casos de estupro, também não deve ser concebida como um compromisso do referido governo em prol das amplas pautas feministas sobre o tema, não obstante este governo também tenha subscrito o primeiro Plano Nacional de Políticas para as Mulheres, onde se previa a revisão da punição das práticas abortivas. Mais uma vez assinalamos que esta norma é também uma batalha, foi parcialmente favorável aos movimentos feministas.

Ainda em termos de Poder Executivo, merece destaque uma fala do ex-ministro da saúde, José Gomes Temporão que, apesar de opinar pela realização de um plebiscito, deixou evidente a sua posição, conforme matéria do globo.com, de 28/03/2007, na qual ele diz:

Isso é, antes de mais nada, uma questão de saúde pública, porque milhares de mulheres morrem todos os anos submetendo-se a abortos inseguros. [...] Sei que é uma questão polêmica, que envolve aspectos morais, religiosos, psicológicos, mas diz respeito, fundamentalmente, à política de saúde.

Não obstante a postura do mencionado ministro, que é médico sanitarista e se alinha com o pensamento dos movimentos que localizam o aborto como problema de saúde pública, não se pode dizer que seu posicionamento tenha expressado o pensamento do governo que ele representava, qual seja, o de Luís Inácio Lula da Silva, posto que não houve por parte do referido chefe de Estado nenhum pronunciamento público e oficial neste sentido. Aliás, a ausência de pronunciamentos oficiais e a própria postura ambígua e incerta não apenas dos governantes, mas de outros ocupantes de ministérios de esquerda no Brasil, fezse sentir em vários momentos ao longo dos mandatos do Partido dos Trabalhadores; prova disto é a posição de Eleonora Menicucci, veterana feminista que ocupou o cargo de Secretária Especial de Políticas para as Mulheres (SPM), entre os anos de 2012 e 2015, no governo de Dilma Rousseff. Ao assumir o mencionado cargo, ela declarou:

Eu já dei entrevistas, sobretudo nos anos 70, 80 e 90, quando o feminismo necessitava de marcar posições e muitas mulheres ousaram dizer até da sua vida privada. Não me arrependo, mas, a partir de sexta-feira [data de sua posse], eu sou governo e a matéria da legalização ou descriminalização do aborto é uma matéria que não diz respeito ao Executivo, diz respeito ao Legislativo. (MENDES, 2012, on-line).

Outro episódio bastante ilustrativo da ambiguidade e recuos de governos dos quais se esperavam posturas mais progressistas sobre o tema em apreço ocorreu em 2014, quando o Ministério da Saúde do governo Dilma Roussef divulgou a portaria 415/2014 (BRASIL, 2014), que versava sobre inclusão do aborto, por razões médicas e legais, na Tabela de Procedimentos do SUS, mas tratou de revogá-la em menos de uma semana, sem qualquer justificativa. Ato contínuo, o então deputado federal, Eduardo Cunha, deu entrevistas à imprensa, agradecendo ao ministro Arthur Chioro por ter se antecipado em revogar o referido documento, informando, outrossim, que o havia alertado sobre a apresentação de um projeto de decreto legislativo exatamente neste sentido (MATOSO, 2014).

Os fatos e pronunciamentos acima expostos apresentam indícios de como a pauta do aborto ainda é desafiadora, complexa e, muitas vezes, tratada de forma contraditória no âmbito do Executivo brasileiro, fazendo com que os malabarismos retóricos sejam construídos e disseminados a fim de manter os governantes a salvo do julgamento moral, da opinião pública, dos aliados do governo, da própria oposição, 
dado o caráter polêmico do tema e a dificuldade de seu tratamento, de forma aberta, racional, numa sociedade majoritariamente cristã e bastante conservadora como a nossa.

Afirmamos, anteriormente, que dos seis presidentes que ocuparam o Palácio do Planalto desde a promulgação da Constituição Federal, nenhum deles atuou de forma expressa, concreta e proativa em prol do tema do aborto. Porém, para não dizer que nem o governo Dilma Rousseff teve qualquer atitude mais corajosa e de proatividade em favor das demandas das mulheres no que tange à pauta do aborto ou a ela correlata, vale registrar que a presidenta sancionou, sem vetos, a Lei n 12.845/2013, fruto do PL nº 60/99, proposto em 1999 pela deputada lara Bernardi (PT/ $\mathrm{SP})$, cujo objetivo, conforme já exposto, é garantir o atendimento imediato e multidisciplinar, mediante controle e tratamento, tanto do ponto de vista físico quanto emocional, das vítimas de violência sexual ${ }^{24}$.

0 referido projeto tramitou a passos de tartaruga entre 1999 e 2013, isto é, por longos 14 anos e, foi submetido sob o número 3/2013, para votação no plenário da Câmara, em regime de urgência ${ }^{25}$, tendo em vista 0 contexto das comemorações do 8 de março de 2013. A votação do mencionado PL transcorreu sem qualquer oposição e/ou resistência por parte de parlamentares ou líderes partidários. Porém, quando encaminhado para sanção presidencial, a chamada Bancada Religiosa passou a se mobilizar contra o mesmo (FALCÃO, 2013). A resistência em questão se referia à expressão "profilaxia da gravidez", constante de um dos artigos da lei ${ }^{26}$, que foi interpretada, pelos representantes da mencionada bancada, como interrupção de gestação, em vez de ser compreendido como contracepção.

\footnotetext{
24 Com a aprovação desta lei, todos os hospitais integrantes do SUS tem o dever de: 1) fazer o diagnóstico e o tratamento das lesões físicas no aparelho genital e demais áreas afetadas; 2) fornecer amparo médico, psicológico e social; 3) facilitar o registro da ocorrência e encaminhá-la a órgãos de medicina legal e delegacias especializadas com informações que possam ser úteis à identificação do agressor e à comprovação da violência sexual; 4) fazer a profilaxia da gravidez e de doenças sexualmente transmissíveis, assim como coleta de material para exame de HIV; e 5) fornecer informações às vítimas sobre os direitos legais e serviços disponíveis.

25 Conforme requerimento número 6906/201, do deputado José Guimarães (PT/CE).

26 Vide artigo 40, inciso IV da Lei $n^{0} 12.845 / 2013$
}

Antes de se posicionar, por meio de veto ou sanção, Dilma Rousseff, recebeu parlamentares e representantes de igrejas evangélicas ${ }^{27}$, bem como ativistas dos direitos das mulheres. Porém, sua decisão final foi por sancionar a lei sem restrição, observando orientações técnicas de diversos setores do governo, mormente do Ministério da Saúde (CHAGAS, 2013). Há quem diga, no entanto, que a referida sanção, emitida em dissonância com os interesses da bancada religiosa e dos próprios aliados políticos deste espectro, impactou negativamente sobre o governo Dilma, sendo também responsável pelo seu impedimento de prosseguir na chefia do Executivo. Não subestimamos o referido argumento, todavia, entendemos que o impeachment da primeira mulher presidenta do país não pode ser explicado de maneira simplista ou unidimensional.

\subsection{ABORTO NA CÚPULA DO PODER JUDICIÁRIO NACIONAL}

Quanto ao Poder Judiciário, pode se dizer que este, apesar de seu atávico conservadorismo e elitismo institucional, tem sido palco de grandes discussões nacionais sobre o aborto, muito mais do que o Parlamento e o Executivo Nacional, em termos proporcionais e considerando a natureza de suas atribuições. Vale pontuar, todavia, que estamos nos referindo à cúpula do Judiciário brasileiro, isto é, ao Supremo Tribunal Federal, cujas decisões têm caráter obrigatório, abrangente e vinculante sobre os demais tribunais do país e a totalidade dos magistrados brasileiros.

Obviamente que o tema do aborto nunca foi - e continua não sendo - visto de forma homogênea pela Justiça brasileira. Todavia, o STF tem cumprido um papel importante no enfrentamento desta questão, sobretudo nos últimos três a cinco anos, incorporando aos seus argumentos reflexões que dialogam com as proposições e produções científicas desenvolvidas por pesquisadoras feministas. Um dos exemplos desta aproximação entre os argumentos jurídicos e o pensamento feminista sobre o aborto, pode ser extraído

27 Em julho de 2013, o bispo Marcelo Crivella, então ministro da Pesca do governo Dilma, compareceu ao gabinete presidencial acompanhado de cantoras do mundo gospel a fim de orar e convencer a presidenta a refletir sobre o teor daquela norma. 
do julgamento de uma ação de habeas $\operatorname{corpus}^{28}$ ocorrido em 2016, que tinha como autoridade coatora o Superior Tribunal de Justiça do Rio de Janeiro e como pacientes alguns profissionais acusados da prática de aborto numa clínica sediada na capital fluminense.

Em seu voto, anexado ao referido processo, o ministro Roberto Barroso destacou diversos aspectos de ordem social e política referentes à temática do aborto, além de propor uma interpretação conforme à Constituição dos artigos do Código Penal que tratam desta matéria ${ }^{29}$. Transcrevemos, abaixo, uma passagem importante:

\begin{abstract}
[...] é preciso conferir interpretação conforme a Constituição aos próprios arts. 124 a 126 do Código Penal - que tipificam o crime de aborto - para excluir do seu âmbito de incidência a interrupção voluntária da gestação efetivada no primeiro trimestre. A criminalização, nessa hipótese, viola diversos direitos fundamentais da mulher, bem como o princípio da proporcionalidade. A criminalização é incompatível com os seguintes direitos fundamentais: os direitos sexuais e reprodutivos da mulher, que não pode ser obrigada pelo Estado a manter uma gestação indesejada; a autonomia da mulher, que deve conservar o direito de fazer suas escolhas existenciais; a integridade física e psíquica da gestante, que é quem sofre, no seu corpo e no seu psiquismo, os efeitos da gravidez e a igualdade da mulher, já que homens não engravidam e, portanto, a equiparação plena de gênero depende de se respeitar a vontade da mulher nessa matéria (grifo nosso).
\end{abstract}

Além de destacar demandas e direitos das mulheres historicamente reivindicados pelos movimentos feministas no Brasil, o ministro referido ainda acrescentou argumentos relativos à situação das mulheres pobres no país, bem como o elevado índice de casos de lesões e mortes geradas pela prática do aborto inseguro e clandestino, conforme expomos a seguir, literalmente:

A tudo isto se acrescenta o impacto da criminalização sobre as mulheres pobres. É que o tratamento como crime, dado pela lei penal brasileira, impede que estas mulheres, que não têm acesso a médicos e clínicas privadas, recorram ao sistema público de saúde para se

28 Ação registrada no STF sob o número 124.306.

29 Manifestação jurídica disponível em: http://www.stf.jus.br/arquivo/ cms/noticiaNoticiaStf/anexo/HC124306LRB.pdf submeterem aos procedimentos cabíveis. Como consequência, multiplicam-se os casos de automutilação, lesões graves e óbitos30.

O mencionado jurista frisou, ainda, que o tratamento penal da problemática do aborto não é medida adequada para seu enfrentamento, vez que "não produz impacto relevante sobre o número de abortos praticados no país”, mas ao contrário, apenas dificulta a sua realização segura. Destacou, também, que o Estado poderia evitar um maior número de ocorrência de abortos por meios mais eficazes que não a criminalização, sugerindo a educação sexual, a distribuição de contraceptivos e o próprio "amparo à mulher que deseja ter filho, mas se encontra em condições adversas”.

Ainda pontuou, em consonância com várias contribuições feministas sobre o tema, que a criminalização do aborto é uma medida desproporcional em sentido estrito, pois gera custos sociais elevados, como problemas de saúde pública e alto índice de mortes, que são superiores aos eventuais benefícios de se manter opção jurídica e política atual. Por fim, o ministro Barroso alegou que os países considerados desenvolvidos e as democracias consolidadas, já não tratam como crime a interrupção voluntária da gravidez até o primeiro trimestre, citando, dentre eles, os Estados Unidos, a Alemanha, o Reino Unido, o Canadá, a França, a Itália, Espanha, Portugal, Holanda e Austrália.

A posição mencionada foi adotada em 2016, no julgamento suprareferido, porém, doze anos antes, mais precisamente em 2004, a luta das mulheres pela ampliação do direito de escolha em termos de maternidade, já ganhava um novo fôlego a partir da opção por um litígio estratégico31 junto ao STF. Na ocasião, teve início um dos mais amplos e tensos debates acer-

30 Manifestação jurídica disponível em http://www.stf.jus.br/arquivo/ cms/noticiaNoticiaStf/anexo/HC124306LRB.pdf

31 Litígio estratégico é o uso estratégico do direito, ou de alguma ação judicial específica, visando a ampliação da cidadania ou a defesa de interesses de grupos ou segmentos historicamente discriminados, excluídos ou vulneráveis no seio da sociedade. Pode ser considerado também como a incidência política junto ao Legislativo ou Executivo com vistas à formulação de leis e políticas públicas em prol dos direitos humanos. É dito estratégico porque tem um caráter emblemático capaz de gerar precedentes ou resultados positivos sobre determinado tema ou questão controversa ou de difícil solução pelos caminhos convencionais. Em regra, são escolhas que permitem grandes saltos em matéria de direitos humanos. 
ca da questão do aborto no país, provocado por uma Ação de Descumprimento de Preceito Fundamental, a ADPF54 - cujo objetivo era solicitar ao Supremo que procedesse à interpretação conforme à Constituição, dos artigos 124, 126 e 128 do Código Penal (que criminalizam o aborto), visando reconhecer a inconstitucionalidade da aplicação de tais normas em situações de mulheres gestantes de fetos anencéfalos.

Esta ação foi proposta pela Confederação dos Trabalhadores na Saúde (CNTS), em parceria com o Instituto de Bioética, Direitos Humanos e Gênero (ANIS)32. Este debate se arrastou por 8 anos, tendo fim no 13 de abril de 2012, quando 8 dos 11 ministros do Supremo Tribunal Federal votaram favorável à referida ação e declararam inconstitucional a interpretação segundo a qual a interrupção da gravidez de anencéfalos deveria ser tipificada nos artigos 124, 126, 128, incisos I e II, do Código Penal.

No tópico a seguir, expomos, com brevidade, o caráter dos argumentos contrários e favoráveis à descriminalização do aborto no caso de anencefalia, pois, não obstante se trate de argumentos apresentados em face de uma situação específica, é possível verificar que o teor das ideias em confronto, apresentadas de parte a parte, se aplica, no que couber, a outros casos de aborto, uma vez que as formulações se pautam em postulados éticos, morais, políticos ou científicos que tem caráter generalizante na matéria em apreço.

\section{ARGUMENTOS CONTRA E A FAVOR DO ABORTO EM CASO DE ANENCEFALIA}

Marta Rodriguez de Assis Machado e Ana Carolina Bracarense (2018), em artigo específico sobre o tema, destacam as estratégias argumentativas utilizadas pelos movimentos pró e antiaborto durante audiências públicas relacionadas a fetos anencéfalos realizas pelo Supremo Tribunal Federal durante o ano de 2008. As autoras analisaram argumentos desenvolvidos por diversos atores sociais interessados no assunto, todos vinculados aos seguintes grupos 32 Importante organização do campo pró-aborto no Brasil. e organizações com atuação nacional: Conferência Nacional dos Bispos do Brasil (CNBB); Igreja Universal do Reino de Deus; Associação Nacional Pró-Vida e Pró-Família; Católicas pelo Direito de Decidir; Associação Médico-Espírita do Brasil (AME); Instituto de Bioética, Direitos Humanos e Gênero (ANIS); Associação de Desenvolvimento da Família (ADEF); Escola de Gente; Rede Nacional Feminista de Saúde, Direitos Sexuais e Direitos Reprodutivos; Conectas Direitos Humanos e Centro de Direitos Humanos (Conectas); Movimento Nacional da Cidadania em Defesa da Vida - Brasil Sem Aborto.

As organizações que se posicionaram publicamente contra a interrupção terapêutica da gravidez de anencéfalos foram: CNBB, AME, ADEF e Associação Nacional Pró-Vida e Pró-Família. Conforme as pesquisadoras, todas as falas estiveram alinhadas sob um mesmo argumento: a defesa do valor da vida e o reconhecimento do feto anencélafo como portador deste direito (MACHADO; BRACARENSE, 2018). De modo sintético, e com arrimo nas palavras das citadas pesquisadoras, destacamos a seguir algumas estratégias discursivas dos defensores da tese de que as mulheres devem levar a cabo uma gravidez de feto considerado natimorto:

A CNBB defendeu a humanidade do ser em gestação,
ainda que tenha malformação, e invocou o respeito à
dignidade da pessoa humana. A vida seria um valor
inviolável que não poderia ser considerado inferior a
qualquer outro - inclusive a dignidade da mãe, quem
terá que encontrar meios para superar o sofrimento
e continuar com a gravidez -. No mesmo sentido ar-
gumentou a AME: "nós estamos falando de vida. Ouço
falar de direitos da mulher. Não há direito da mulher
quando estamos falando de um direito que o sobre-
põe, que é o direito a vida". Sobre este argumento é
importante notar a semelhança em sua forma com o
modo de argumentação tipicamente jurídico em ques-
tões constitucionais, a ponderação e sopesamento de
valores. Também na defesa da vida, a médica que re-
presentou a ADEF mencionou o juramento de Hipócra-
tes: "Manterei o mais alto respeito pela vida humana".
Todas estas organizações estiveram representadas por
médicos ou cientistas. No caso da CNBB se tratou de
um sacerdote que é também doutor em bioética. (MA-
CHADO; BRACARENSE, 2018, p. 122 , tradução nossa) 
Um aspecto interessante destacado pelas autoras e que nos convida à reflexão, é o fato de que a única entidade, dentre as supra referidas, que sustentou posição baseada em argumentos estritamente religiosos, fazendo frequentes referências à Bíblia para tratar da "vida desde a concepção", foi a CNBB, representada por líderes católicos. As demais entidades apresentaram seus pontos de vista sem mencionar valores religiosos, mas, conforme faziam questão de frisar, baseados na ciência e em pesquisas de opinião pública.

Sobre este fato, entendemos que o apelo à ciência é absolutamente estratégico, pois enquanto religiosos e não detentores de mandatos, sabem que no seio de um Parlamento e, sobretudo no contexto de um Estado laico e democrático, argumentar sobre aborto somente com base nas suas crenças ou Escrituras Sagradas pode não surtir efeito, o que justifica o apelo à ciência, uma vez que muitos deles, além de se dedicaram aos estudos teológicos também têm estudos acadêmicos ou cultivam estreitas relações com docentes e discentes deste campo. Todavia, este apelo às pesquisas de opinião ou a alguma abordagem científica não isenta tais argumentos da crítica ou do escrutínio público por parte de outros cientistas, afinal, como adverte Débora Diniz (2010), é preciso colocar em xeque não apenas o modo de coleta destas pesquisas, mas os seus fundamentos epistêmicos e o caráter de suas análises.

De todo modo, vale registrar que cada uma das organizações que se opunham ao aborto de anencéfalos, nas mencionadas audiências, se esmeraram em apresentar suas ideias e posições, visando influenciar os magistrados do STF diante do debate em questão.

Já as organizações que que se posicionaram publicamente favoráveis à interrupção da gravidez de fetos com anencefalia foram: Católicas pelo Direito de Decidir; Instituto de Bioética, Direitos Humanos e Gênero (ANIS); Rede Nacional Feminista de Saúde, Direitos Sexuais e Direitos Reprodutivos; Conectas Direitos Humanos e Centro de Direitos Humanos (CONECTAS), Escola de Gente e Igreja Universal do Reino de Deus. Tais organizações divergiram das que se posicionam de modo contrário a ADPF em comento por entender que a anencefalia é uma prova da inviabilidade da vida. Além disto, argumentaram que a interrupção da gravidez em caso de fetos anencéfalos é totalmente diferente do debate de aborto voluntário, pontuando que a situação da anencefalia traz um diagnóstico irreversível.

Acerca disto e pondo ênfase na laicidade do Estado, a feminista Jaqueline Pitanguy, representante do Conselho Nacional dos Direitos da Mulher (CNDM), se manifestou nos seguintes termos, durante audiência pública do STF ocorrida em 4/9/2008 33 :

\begin{abstract}
Trata-se, assim, de defender um direito à escolha da mulher, que se desejar levar a termo a gravidez nestas circunstâncias está amparada pela lei e pelos serviços de saúde, entretanto, a não permissão legal para a interrupção legal da gravidez quando a gestante assim o deseja é um grave desrespeito a seus direitos. Prevalece um concepto sem qualquer possibilidade de vida sobre uma cidadã plenamente capaz de tomar decisões e arcar com as suas consequências. Essa mulher é cidadã de um país democrático, plural e regido por um Estado laico. A separação entre igreja e Estado é um pilar da nossa República e a sua defesa é fundamental para que os direitos civis, políticos, sexuais e reprodutivos de todos os brasileiros e brasileiras que, com crenças religiosas e filosóficas diversas convivem como cidadãos e cidadãs com igualdade de direitos e deveres.
\end{abstract}

As manifestações de Pitanguy, embora representassem a posição de um Conselho de Direitos que trata dos interesses de um público específico, qual seja, as mutheres e, apesar de ser um órgão vinculado ao governo federal, do qual ela era presidenta, também repercutiam a visão de entidades não governamentais que se posicionavam a favor da ADPF 54 no âmbito do SFT naquela ocasião, pois todos estes grupos compartilham do entendimento de que a escolha cabe sempre à mulher.

Outro ponto comum nos argumentos das organizações que opinaram a favor da procedência da ação em comento, é que todas faziam questão de enfatizar que o debate não se tratava do tema do aborto em si,

33 A íntegra da fala da referida socióloga pode ser acessada em vídeo específico, com início aos 19 minutos, tal vídeo se encontra disponível em https://www.youtube.com/watch?v=cJe7fBD7I-M\&index=5\&list=PLippyY 19Z47vGsw8_FF1gBWqzkSv7njE2 
mas da “antecipação terapêutica do parto”, considerada uma expressão menos dolorosa para as mulheres que viveram ou vivem esta experiência. Neste particular, somente a Igreja Universal do Reino de Deus, representada na ocasião pelo bispo Carlos Macedo de Oliveira ${ }^{34}$, divergiu da abordagem, pois, em que pese ter se posicionado a favor da ADPF e, portanto, pelo direito de escolha da mulher grávida que se depara com a situação em exame, destacou que o pleito reacendia, sim, o debate sobre o aborto e que este é polêmico e conflita com diversas convicções religiosas ${ }^{35}$.

Vale pontuar, todavia, que dentre as entidades religiosas presentes nas audiências sobre o tema, somente a associação Católicas pelo Direito de Decidir e a Igreja Universal do Reino de Deus se manifestaram favorável às mulheres, reiterando a importância da laicidade do Estado, mesmo quando faziam eventuais referências a suas crenças e valores no contexto de suas argumentações. Este destaque é importante, porque possibilita desmontar uma visão estereotipada acerca das pessoas e das instituições religiosas, sobretudo as evangélicas, pois no seio dos movimentos sociais de um modo geral e dos movimentos feministas em particular, ainda circulam opiniões que colocam todos os cristãos no mesmo balaio, o que dificulta a construção de alianças, articulações e lutas em prol dos direitos de determinados grupos dos quais religiosos também fazem parte, como mulheres, negras/os e Lésbicas, Gays, Bissexuais, Travestis, Transexuais ou Transgêneros (LGBT) etc.

Os argumentos acerca da autonomia da mulher, presentes nas falas de representantes da Rede Feminista de Saúde, do Instituto Anis e da Conectas, dentre outras, também caracterizaram os discursos das Católicas pelo Direito de Decidir e do bispo da Igreja Universal, o que demonstra, novamente, que há possibilidades de se pensar os direitos das mulheres e as estratégias de sua defesa a partir de

34 Síntese da manifestação do bispo pode ser localizada às folhas 19 do processo de ADPF. Disponível em http://redir.stf.jus.br/paginadorpub/paginador.jsp?docTP=TP\&docID=3707334

$35 \mathrm{~A}$ fala do mencionado pastor no âmbito da audiência pública do dia 26 de agosto de 2008, no STF, pode ser localizada aos 7 minutos e 35 segundos do vídeo específico. Disponível em https://www.youtube.com/watch?v=tqa4b Pkcnkk\&list=PLippyY19Z47vGsw8_FF1gBWqzkSv7njE2\&index=12 abordagens e perspectivas sociais diversas, sendo importante construir ações conjuntas com quem defenda posições semelhantes.

Ademais, e no contexto das mencionadas audiências, as feministas também fizeram analogia entre a experiência das mulheres gestantes de fetos anencéfalos e a situação de quem vive práticas de tortura, pois, segundo Machado e Bracarense (2018), ativistas e pesquisadoras como Lia Zanotta, Débora Diniz e Eleonora Menicucci - representando, respectivamente a Rede Feminista de Saúde, a Anis e a Conectas -, pontuaram que o sofrimento das mulheres grávidas diante do diagnóstico de anencefalia é inimaginável, sobretudo para os homens, posto que, conforme depoimentos das que vivenciaram este trauma, é uma dor dilacerante, e um sofrimento atroz, carregado de medo, incertezas e sofrimento.

Destacaram, todavia, que a tortura não reside em estar grávida de um feto com este diagnóstico, mas na obrigação de manter a gestação e esperar para enterrar o filho depois de morto. Identificou-se que se trata de um ato de tortura do Estado sobre as mulheres, com sucessivos direitos violados.

A Associação Nacional Pró-Vida, por seu turno, também não mediu esforços para argumentar contrariamente à $A D P F$, invocando uma situação específica e totalmente excepcional, denominada "caso Marcela”. Trata-se do caso de uma menina diagnosticada anencéfala que sobreviveu, fora do útero, por aproximada um ano e dois meses. Diante disto, tanto a CNBB como a ADEF, se referiram à antecipação terapêutica do parto de anencéfalos como "aborto eugenésico", destacado-o ainda como "uma ação discriminatória e racista” contra seres indefesos (MARCHADO; BRACARENSE, 2018, p. 127).

Ainda no âmbito dos debates ocorridos no STF durante o ano 2008, uma médica representante da ADEF fez menção ao "risco de se avaliar um ser humano somente por sua eficiência” e não pela tolerância com qualquer tipo de imperfeição. Neste particular, a organização Escola de Gente, enquanto entidade que atua na defesa dos direitos de pessoas com deficiência, tratou de se contrapor a este argumento, destacando que é ne- 
cessário diferenciar um feto anencéfalo de uma pessoa com deficiência, haja vista que não há expectativa de vida para fetos com anencefalia, o que não constitui um ato discriminatório baseado em deficiência.

No contexto, a Escola de Gente mencionou o conceito da Organização das Nações Unidas (ONU) sobre deficiência e destacou que a vida fora do útero é essencial para definir se uma pessoa tem deficiência. De igual modo, o Movimento Brasil Sem Aborto também invocou a ONU, porém para destacar que esta organização proclama que todo ser humano tem direito à vida, sustentando que o anencéfalo é um deficiente "e não um morto vivo" (MARCHADO; BRACARENSE, 2018, p. 127-128).

Os debates sobre o tema não pararam por aí e ambos os lados seguiram se manifestando conforme suas convicções e argumentos decorrentes, cujos conteúdos estão publicamente disponíveis tanto em anais do STF, mormente no relatório deste julgado histórico ${ }^{36}$, como no conjunto de vídeos relativos às audiências públicas, que ocorreram em quatro sessões distribuídas entre os dias 26 e 28 de agosto e 4 e 16 de setembro de $2008^{37}$.

Tais debates, a nosso ver, demonstram como a questão do aborto precisa ser melhor conhecida e, sobretudo compreendida, não somente pela sociedade brasileira, mas pelos poderes constituídos, a quem compete tomar decisões frente a sua ocorrência, seus efeitos e impactos na vida das mulheres e na sociedade como um todo.

\section{DEBATE ATUAL SOBRE ABORTO NO BRASIL E AS CONSTRIBUICÕES FEMINISTAS}

Conforme destacado na obra "A Carta que Elas Escreveram" (SILVA, 2016), o direito ao aborto ainda é uma questão pendente no Brasil e os debates públicos sobre o tema - especialmente os ocorridos no âmbito dos poderes públicos nacionais, assim como as medi36 Disponível em: http://www.stf.jus.br/arquivo/cms/noticianoticiastf/ anexo/adpf54.pdf

37 Todas elas disponíveis em: https://www.youtube.com/ playlist?list=PLippyY19Z47vGsw8_FF1gBWqzkSv7njE2 das de caráter legislativo, administrativo e jurisdicional, adotadas em face deste problema -, evidenciam a dimensão do desafio que ainda temos pela frente, malgrado todos os esforços desenvolvidos pelo movimento feminista brasileiro ao longo das últimas três décadas.

Com efeito, o aborto continua sendo uma das pautas feministas com mais dificuldade de abordagem no seio da nossa sociedade. E isto decorre não apenas em face de um engajado posicionamento contrário à sua descriminalização, articulado pelas forças políticas mais conservadoras e reacionárias da nação - incluindo-se aí representantes das mais diversas igrejas - mas também por conta da resistência social fortemente estimulada e influenciada pela (des)informação midiática acerca do tema, o que dificulta, sobremaneira, o convite à reflexão que poderia ser convocado, com muito mais frequência ainda, pelas mais distintas organizações e instituições sociais, junto às quais os poderes públicos podem e devem atuar, de maneira permanente, na condição de mediador e/ou catalizador das diversas percepções e opiniões, balizadas, obviamente, pelas ideias de Estado laico e aprofundamento da democracia.

Ocorre, portanto, que se trata de um tema que precisa ser discutido à luz das perspectivas e das pesquisas feministas, pois estas se constroem com base nas experiências do grupo social mais diretamente envolvido e afetado com o problema, qual seja, as mulheres de um modo geral e as mulheres das camadas populares em particular, cujos direitos à liberdade, à autonomia dos corpos, à saúde integral e à própria vida, têm sido secundarizados e/ou negligenciados pelo Estado diante do discurso hegemônico e sua persistência na criminalização (ÁVILA, 2004; DINIZ; MEDEIROS, 2010)

No momento presente e em face de uma nova ação judicial $^{38}$ que tramita no Supremo Tribunal Federal, o debate está reaberto e mais aceso do que nunca. Porém, e apesar de sua importância e atualidade, além 38 Ação de Descumprimento de Preceito Fundamental (ADPF), de número 442, proposta em 2017, pelo PSOL, argumenta, fundamentalmente, que os artigos do Código Penal que proíbem o aborto estão em desacordo com preceitos fundamentais da Constituição Federal, tais como: o direito das mulheres à própria vida, à dignidade, à cidadania, à não discriminação, à liberdade, à igualdade, à saúde e ao planejamento familiar, dentre outros. 
das excelentes contribuições teóricas apresentadas por feministas brasileiras, o fato é que, trinta anos depois do processo constituinte, ainda nos deparamos com velhos e insustentáveis argumentos de que este tema não deve ser objeto de análise na cúpula do Judiciário, pois "a Justiça deveria se ocupar de coisas mais importantes" ${ }^{39}$, havendo também quem diga que o assunto não deveria ser abordado como direito ou questão de saúde pública, haja vista se tratar de "um pecado imperdoável" 40 ou de questão de índole moral, levantada, sobretudo, por homens que acorrem a argumentos religiosos e pseudocientíficos para manter seus privilégios de gênero, raça e posição social ${ }^{41}$.

A diferença, no entanto, é que agora temos uma Corte Constitucional que já vem se manifestando positivamente pela descriminalização da referida conduta e um movimento feminista cada vez mais maduro e animado com as recentes manifestações e votações ocorridas na Argentina ${ }^{42}$.

Apesar do exposto, em recente audiência pública convocada pelo STF sobre o tema, ocorrida em 3/8/2018, foi oportunizada, mais uma vez, a participação da pesquisadora Débora Diniz, uma das maiores autoridades sobre o tema no Brasil, cujas exposições têm contribuído fortemente para a desconstrução de argumentos androcêntricos, conservadores e/ou pouco confiáveis sobre o tema. Sobre isto, ela diz:

Nem tudo vale. Os dados não estão aí e eles não falam por sim mesmos [...] não basta se apresentar aqui como cientista ou mesmo ter um título de doutorado para ser confiável a um debate sobre algo de tamanha importância que é a criminalização do aborto no Brasil. Há

\footnotetext{
39 Fala de um pastor evangélico em pregação pública realizada durante "o mês da mulher" em 2015, na cidade do Rio de Janeiro, compartilhada por ativistas cariocas em grupo de estudiosas sobre tema.

40 Manifestação de padre católico em pleno horário nobre em televisão aberta.

41 Como os autores dos projetos de lei elencados no quadro 1 do presente artigo.

42 A luta pelo aborto legal na Argentina demonstrou, no mês de julho de 2018, que a Câmara dos Deputados está bastante atenta às demandas das mulheres naquele país, assim como uma grande parcela da sociedade, que se manifestou, publicamente, pela descriminalização desta prática. No entanto, em agosto do mesmo ano, o Senado argentino rejeitou a proposta, em votação apertada, tendo 38 votos contra, 31 a favor, e duas abstenções. De todo modo, o feminismo na Argentina é um dos mais altivos da América do Sul, sobretudo em matéria de direitos sexuais e reprodutivos para as mulheres.
}

regras do jogo que devem ser respeitadas antes de se solucionar uma controvérsia constitucional como esta [...] precisamos fazer uma pergunta de quem produziu essas evidencias, onde elas foram disseminadas e como era foram coletadas. Isso nós chamamos em ciência de evidências confiáveis. Um estudo sobre aborto, por exemplo, que venha afirmar que $86 \%$ da população brasileira é contra o aborto tem um erro de partida, que em geral são os erros de pesquisa de opinião sobre temas tão controversos como aborto.[...] Estas pesquisas não seriam publicada em nenhuma revista confiável da comunidade acadêmica, e servem talvez como manchete de jornal ou peça de retórica de construção sobre argumentos em um tema controverso ${ }^{43}$.

Segundo Diniz (2018), quando se trata de pesquisa de opinião sobre o aborto no Brasil, o problema não está na amostra em si, ou na coleta, mas na pergunta. Pois o que importa não é a opinião das pessoas, mas sim suas práticas, uma vez que, de acordo com a pesquisadora, uma mesma mulher pode se posicionar contra o aborto em uma dada pesquisa de opinião e ter praticado um ou mais abortos; afinal, conforme aduz, a aparente incoerência pode ser perfeitamente compreendida quando devidamente examinado o contexto e - como ela enfatiza - quando estamos diante de perguntas inquisitoriais, formuladas com base na da lei penal, que geram uma expectativa de resposta específica, dado que naturalizam a ameaça de prisão, tendemos a ser incoerentes, opinando contrariamente àquilo que praticamos.

Com esta constatação, a antropóloga feminista desmistifica certas pesquisas, sobretudo de opinião, que acreditam estar revelando a verdadeira realidade do aborto no Brasil, quando, na verdade, não tem sequer o condão de expor a ponta do iceberg, dado que a problemática é muito mais complexa e profunda.

Ainda de acordo com Débora Diniz (2018)44, o mapa do aborto no Brasil45 evidencia que uma em cada cin-

43 Disponível em https://www.youtube.com/watch?v=3dB5SSRC01M 44 Vídeo de participação da pesquisadora Débora Diniz em audiência no STF - 03/08/18. Disponível em: https://www.youtube.com/ watch?v=3dB5SSRC01M

45 Este mapa consta da "Pesquisa nacional do aborto", já mencionada neste artigo. A mesma foi desenvolvida em 2010, em diversas regiões do país, sob a coordenação da própria Débora Diniz. Para tanto, contou com auxílio do Ministério da Saúde e foi aplicada em mulheres entre 18 e 39 anos, residentes na zona urbana (DINIZ; MEDEIROS; MADEIRO, 2017). 
co mulheres, na faixa dos 40 anos, já fizeram um aborto na vida e a maioria delas o praticou entre os 20 e 24 anos. Muitas delas, segundo a pesquisadora, têm filhos atualmente, mas já se depararam com dificuldades que não lhes permitiram levar adiante uma gestação. Ademais, são, em sua maioria, mulheres comuns do povo, sem acesso a grandes recursos, sem elevada instrução escolar, muitas delas são cristãs e residem, em sua maioria, no Norte e Nordeste do país.

Em termos quantitativos, segundo dados do Senado, divulgados em 2015, ocorrem no Brasil de um milhão a um milhão e quinhentos abortos por ano, mas a própria Débora Diniz alerta para a subnotificação dos números, considerando que se trata de prática tida como criminosa e, portanto, clandestina. A pesquisadora reitera que o perfil das mulheres que abortam não coincide com o que o senso comum deduz, pois são mutheres comuns e a criminalização do aborto leva muitas delas à morte. Em face disto, a pesquisadora sustenta que o aborto não deve ser matéria de prisão, mas de cuidado e proteção, enfatizando, ainda, que há uma distribuição desigual do risco, pois este é bem maior entre jovens, negras, pobres nortistas e nordestinas.

\section{CONSIDERAÇOES FINAIS}

Neste artigo, apresentamos um panorama histórico-crítico dos principais debates públicos em torno da temática do aborto no Brasil. No primeiro tópico, registramos o momento de sua introdução na agenda política nacional, seguido de uma breve exposição sobre o seu tratamento na Assembleia Nacional Constituinte de 87/88. Num terceiro momento, destacamos, no âmbito dos poderes Legislativo, Executivo e Judiciário, alguns momentos em que o tema esteve em pauta em cada um destes espaços. Sequencialmente, pontuamos, ainda que in passant, alguns dos argumentos favoráveis e contrários à descriminalização da prática, focando, precisamente, os debates em torno dos casos de anencefalia. Por final, de forma resumida, apresentamos o contexto atual e as contribuições feministas em torno da problemática.
0 artigo evidenciou que a luta das mulheres brasileiras em torno da questão do aborto já vem de longínqua data, mas ainda tem muito chão pela frente, haja vista que, conforme foi demostrado, ainda há muitas resistências no âmbito da sociedade e nos próprios poderes constituídos no que tange ao alargamento das possibilidades de aborto, bem como à pauta da sua descriminalização e legalização.

No contexto do poder Executivo, tímidas são as ações que se ocupam desta questão, restringindo-se, na maioria dos governos, ao regulamento e cumprimento, ainda que de forma sofrível, dos casos de aborto legal devidamente previstos em norma penal produzida na década de 1940.

Quanto ao Legislativo, embora a crescente discussão sobre a temática no contexto da Câmara e do Senado, ao longo das últimas três décadas, tantos os projetos de lei, como os discursos hegemônicos tem se dado no sentido de fortalecer o status quo jurídico e social, quando não se apresentam flagrantemente favoráveis ao seu próprio retrocesso. Há, na verdade, uma ascensão dos discursos conservadores e um inegável recuo por parte das forças consideradas progressistas, algo que também foi constatado por outras pesquisas (MIGUEL, 2012; ALMEIDA; BANDEIRA, 2013; SANTOS, 2015; BIROLI, 2016; MACHADO, 2016).

$\mathrm{Na}$ esfera do Judiciário, ao menos no STF, tem havido alguns progressos, notadamente em face dos litígios estratégicos interpostos por meio de ações que possibilitam um maior debate e uma participação social devidamente qualificada para enfrentar a questão. Neste espaço, o pensamento feminista tem ganhado terreno, inclusive tem sido incorporado, ainda que timidamente, em votos de magistrados, o que constitui um ganho de bastante relevância.

$\mathrm{Na}$ atualidade, está em discussão no âmbito do Supremo uma Ação Constitucional - ADPF 442 - proposta pelo Partido Socialismo e Liberdade (PSOL) e que pode ter desdobramentos bastante favoráveis às mulheres brasileiras, embora sempre exista o risco da morosidade ou mesmo de algum revés quanto ao que se espera. Mas, a presença das feministas, com falas qualificadas, nas audiências públicas transmitidas em 
tempo real e acompanhadas pela sociedade brasileira já é bastante educativa não somente do ponto de vista da amplificação do discurso, mas das possibilidades de reflexão e indução de processos empoderadores, dentro e fora das organizações e movimentos sociais dedicadas à temática. Também constitui um ganho do ponto de vista democrático, pois se trata de uma temática que outrora era escanteada e hoje ocupa a pauta da mais alta corte jurídica do país.

Na mesma esteira, encontra-se em trâmite no Senado Federal, a Sugestão Legislativa (SUG 15/2014), já citada neste artigo, que visa regular a interrupção voluntária da gravidez, dentro das doze primeiras semanas de gestação, pelo Sistema Único de Saúde. Tal sugestão enviada por meio do Portal e-cidadania ${ }^{46}$, da referida casa legislativa, também constitui um importante avanço nos debates em torno do tema, especialmente por se tratar de proposta legislativa oriunda da sociedade civil, mediante proposição de um cidadão comum, simpatizante das demandas das mulheres e defensor da igualdade de gênero em todas as esferas da vida social. As audiências públicas que esta ideia gerou também possibilitaram participações diversas e foram igualmente educativas não apenas para as e os parlamentares, mas para a sociedade que a acompanhou por meio da televisão ou das mídias sociais.

Isto posto, pode se dizer que, apesar da maioria dos projetos de lei propostos ao longo dos últimos trinta anos ser voltada para a restrição ou ameaças de eliminação dos direitos das mulheres na seara da reprodução e sexualidade, há, todavia, iniciativas como a acima mencionada que partem do próprio povo e que se coadunam com as demandas das mulheres organizadas no Brasil em torno do tema do aborto.

Tal iniciativa, somada à atuação do STF e à intensa e qualificada participação das pesquisadoras e ativistas feministas nas audiências públicas realizadas no Judiciário e no Parlamento, constituem medidas e proposições relevantes e necessárias à continuidade da luta em prol da descriminalização e legalização do aborto no país, mormente diante do 46 Mecanismo online e interativo que tem como objetivo estimular a participação de cidadãos e cidadãs nas atividades parlamentares, propondo leis ou se posicionando através dos projetos propostos. avanço da ofensiva conservadora que se coloca contrária à ampliação da cidadania das mulheres, principalmente a partir do ano de 2015.

Ante o exposto, reconhecemos que os movimentos feministas brasileiros, ao longo das três últimas décadas, enfrentaram inúmeros desafios, sobretudo diante da pauta do aborto no país. Mas souberam aproveitar muito bem as parcas oportunidades que apareceram horizonte, especialmente no âmbito dos poderes constituídos, além de promover manifestações e construir argumentações lúcidas e consistentes em prol do avanço das pesquisas em torno da temática no Brasil. Prova disto é que os estudos feministas e de gênero no país têm dado importantes contribuições teóricas ao tema do aborto, expurgando a ênfase estritamente moral da questão, focando em aspectos relacionados à saúde pública e aos direitos humanos das mulheres.

Como se sabe, na maioria dos países onde a prática do aborto ainda não foi legalizada, as discussões sobre este tema têm gerado oposições entre grupos antagônicos, localizando-se de um lado as pessoas que defendem os direitos das mulheres a decidir sobre seus corpos e, de outro, as pessoas (sobretudo homens) que argumentam a favor da vida dos não nascidos. Em síntese, o artigo demonstrou que no Brasil a questão se polariza entre argumentos a favor da proteção de uma vida que ainda não se formou e a autonomia de decisão das mulheres, sendo estas as premissas que caracterizam as discussões sobre 0 aborto em todo o mundo, especialmente a partir da segunda metade do século XX.

As pessoas que se posicionam pró escolha tendem a entender que não cabe ao Estado decidir pelas muIheres algo que diz respeito a suas próprias vidas, pois envolve questões como liberdade e autonomia sobre seus próprios corpos. As que se posicionam pela manutenção da criminalização tendem a apresentar argumentos religiosos ou de cunho moral, sempre fortalecendo uma postura mais conservadora. Assim têm se posicionado muitos políticos - parlamentares sobretudo - de direita e de centro, mas há também muita omissão ou "recuos estratégicos" de políticos de esquerda. 
O aborto segue em pauta no Brasil. E, após trinta anos de Constituição Federal, é chegada a hora de avançar em suas discussões e decisões, afinal, nenhuma mulher (ou homem) que atua em prol de sua descriminalização e legalização está defendendo o aborto como uma prática em si mesma, mas como uma questão de direitos humanos das mulheres, principalmente, além de se tratar de problema de saúde pública. Ademais, a sua descriminalização, seguida da necessária legalização, põe fim ao tratamento penal desta questão social tão complexa, tão escamoteada e a mesmo tempo tão presente entre nós, historicamente. Esta é a discussão que está posta, há trinta anos no país e sua abordagem exige um debate em defesa da laicização do Estado e da radicalização da democracia, que não existem, nem avançam sem a presença e a plena da existência da parcela feminina.

\section{REFERÊNCIAS}

AGÊNCIA SENADO. Aborto divide opiniões em debate na Comissão de Direitos Humanos. Senado notícias, Redação, 06/08/2015. Disponível em: https://www12.senado.leg.br/noticias/ materias/2015/08/06/aborto-divide-opinioes-emdebate-na-comissao-de-direitos-humanos. Acesso em: 10 ago. 2015.

ALMEIDA, Tânia Mara Campos de; BANDEIRA, Lourdes Maria. 0 aborto e o uso do corpo feminino na política: a campanha presidencial brasileira em 2010 e seus desdobramentos atuais. Cadernos Pagu, Campinas, v. 41, 2013. Disponível em http:// periodicos.sbu.unicamp.br/ojs/index.php/cadpagu/ article/view/8645105. Acesso em: 11 ago. 2018

\section{ALENCASTRO, C. Dilma recebeu cantoras gospel} no Palácio do Planalto. 0 Globo, Rio de Janeiro, 16 jul. 2013. Disponível em: https://oglobo. globo.com/ brasil/dilma-recebeu-cantoras-gospel-no-palaciodoplanalto-9041806. Acesso em: 13 ago. 2018.
AMORIM, Paulo Henrique. Mulher de Serra abortou, diz aluna. Conversa Afiada, 16/10/2010. Disponível em: https://www.conversaafiada.com. br/brasil/2010/10/16/mulher-de-serra-abortou-dizaluna-ele-passou-trator-por-cima-da-mulher. Acesso em: 9 ago. 2018.

ANC - Assembleia Nacional Constituinte. Deputada Abigail Feitosa. Diário da Assembleia Nacional Constituinte de 20/5/1987, p. 225-226.

ANC - Assembleia Nacional Constituinte. Discurso Deputada Benedita da Silva. Diário da Assembleia Nacional Constituinte de 21/5/1987, p. 212, $1^{\text {a }}$ coluna.

ÁVILA, Maria Betânia. Democracia, aborto, legalização. Toques de Saúde, João Pessoa, v.4, 2004.

BIROLI, Flávia. 0 aborto em debate na câmara dos deputados. Cfemea, Ipas e Observatório de Sexualidade e Política. 2016. Disponível em: http://redesaude.org.br/comunica/wp-content/ uploads/2016/10/Estudo-Flavia-Biroli-29- 09-2016_ def.pdf. Acesso em: 11 ago. 2018.

\section{BRASIL. Congresso Nacional. Câmara dos} Deputados. Projeto de Lei $\mathbf{n}^{\mathbf{0}} \mathbf{6 0}$, de 1999. Dispõe sobre as vítimas de violência sexual. Brasília, DF, 2013. Disponível em: http://www.camara.gov.br/ proposicoesWeb/ fichadetramitacao?idProposic ao=14993. Acesso em: 13 ago .2018 .

BRASIL. Ministério da Saúde, Secretaria de Atenção à Saúde. Portaria n 415, de 21 de maio de 2014. Inclui o procedimento interrupção da gestação/ antecipação terapêutica do parto previstas em lei e todos os seus atributos na Tabela de Procedimentos, Medicamentos, Órteses/Próteses e Materiais Especiais do SUS. Brasília: Disponível em: Ministério da Saúde, 2014. http://bvsms.saude.gov.br/bvs/ saudelegis/sas/2014/prt0415_21_05_2014.html. Acesso em: 13 ago. 2018. 


\section{CARTA CAPITAL. 0 aborto e as eleições}

presidenciais. Por Celso Marcondes em 30/09/2010 ás 18h46. Disponível em: http://webcache. googleusercontent.com/search?q=cache:pPh F4RUDIIIJ:https://www.cartacapital.com.br/ politica/o-aborto-e-as-eleicoes-presidenciais\&hl=ptBR\&gl=br\&strip=1\&vwsrc=. Acesso em: 2 ago. 2018.

CHAGAS, Tiago. Presidente Dilma decide sancionar lei que pode autorizar o aborto; Pedido de veto da bancada evangélica não foi atendido. Gospel, 1 de agosto de 2013. Disponível em: https://noticias. gospelmais.com.br/dilma-sancionar-lei-aborto-vetonao-atendido-59013.html. Acesso em: 2 ago. 2018.

DINIZ, D.; MEDEIROS, M. Aborto no Brasil: uma pesquisa domiciliar com técnica de urna. Ciência \& Saúde Coletiva, Rio de Janeiro, v. 15, n. 15, p. 959966, jun. 2010.

DINIZ, Debora; MEDEIROS, Marcelo; MADEIRO, Alberto. Pesquisa Nacional de Aborto 2016. Ciência \& Saúde Coletiva, v. 22, n. 2, p. 653-660, 2017. DOI: 10.1590/1413-81232017222.23812016. Disponível em: http://www.scielo.br/pdf/csc/v22n2/1413-8123csc-22-02-0653.pdf. Acesso em: 10 ago. 2018.

ÉBOLI, E. Dilma enfrenta lobby religioso para votar projeto que dá assistência a vítimas de estupro. 0 Globo, Rio de Janeiro, 22 jul. 2013. Disponível em: https://oglobo.globo.com/brasil/dilmaenfrentalobby- religioso-para-vetar-projeto-que-daassistencia-vitimas-deestupro-9118345. Acesso em: 10 ago. 2018.

ESTATUTO do Nascituro avança na Câmara em meio à crise política. Carta Capital. Disponível em: https://www.cartacapital.com.br/sociedade/ estatuto-do-nascituro-avanca-na-camara-em-meioa-crise-politica. Acesso em: 10 ago. 2018

EXPOSIÇÃO dos motivos do novo PL de violência sexual. Blog do Planalto, Brasília, DF, 1 ago. 2013.
Disponível em: http://blog.planalto.gov.br/wpcontent/uploads/2013/08/2013.08.01-Exposição-deMotivos-do-novo-PL-da-violência-sexual.pdf. Acesso em: 4 ago. 2018.

FALCÃO, Marcio. Bancada evangélica critica lei que dá garantia a vítima de estupro. Folha de São Paulo, Brasília, 1/8/2013. Disponível em: https://www1. folha.uol.com.br/cotidiano/2013/08/1320327bancada-evangelica-critica-lei-que-da-garantia-avitima-de-estupro.shtml. Acesso em: 13 ago. 2018.

FALCÃO, M.; GUERREIRO, G. Evangélicos vão atacar lei da pílula do dia seguinte. Folha de S. Paulo, São Paulo, 3 ago. 2013. Cotidiano, p. C7. Acesso em: 13 ago. 2018. Disponível em: https://www1.folha. uol.com.br/cotidiano/2013/08/1320327-bancadaevangelica-critica-lei-que-da-garantia-a-vitima-deestupro.shtml. Acesso em: 6 ago. 2018.

G1. PF apreende panfletos contra Dilma em gráfica de São Paulo. globo.com, São Paulo e Brasília, 17/10/2010. Disponível em: http://g1.globo.com/ especiais/eleicoes-2010/noticia/2010/10/pfapreende-panfletos-contra-dilma-em-grafica-de-saopaulo.html. Acesso em: 10 ago. 2018.

MACHADO, Marta Rodriguez de Assis; BRACARENSE, Ana Carolina. El movimiento pro y antiaborto en el Supremo Tribunal brasileño. Marcos y estrategias argumentativas utilizados en la audiencia pública referente al feto anencefálico. In: BERGALLO, P.; SIERRA, Isabel C. J; MARCO, Juan (org.) El aborto en América Latina. Ciudad Autónoma de Buenos Aires: Siglo XXI Editores Argentina, 2018. p. 111-138.

MATOSO, Filipe. Ministério revoga portaria que incluiu aborto legal na tabela do SUS. G1globo.com, Brasília, 30/05/2014. Disponível em: http://g1.globo. com/bemestar/noticia/2014/05/ministerio-revogaportaria-que-incluiu-aborto-legal-na-tabela-do-sus. html. Acesso em:10 ago. 2018 
MENDES, Priscilla. 'Aborto é questão de saúde pública', diz nova ministra das Mulheres. G1globo. com, Brasília, 07/02/2012. Disponível em: http:// g1.globo.com/politica/noticia/2012/02/aborto-equestao-de-saude-publica-diz-nova-ministra-dasmulheres.html. Acesso em:11 ago. 2018

MIGUEL, Luis Felipe. Aborto e democracia. Estudos Feministas, Florianópolis, v. 20, n. 3, p. 57-672, 2012. Disponível em: https://periodicos.ufsc.br/index. php/ref/article /view/S0104-026X2012000300004. Acesso em: 11 ago. 2015.

MIGULE, Luis Felipe; BIROLI, Flávia; MARIANO, Rayani. $O$ direito ao aborto no debate legislativo brasileiro: a ofensiva conservadora na Câmara dos Deputados. Revista Opinião Pública, Campinas, v. 23, n. 1, p. 230-260, jan./abr. 2017. Disponível em: https:// periodicos.sbu.unicamp.br/ojs/index.php/op/article/ view/8650179/16557. Acesso em: 10 ago. 2018.

MINISTÉRIO da Saúde. Norma Técnica: Prevenção e tratamento dos agravos resultantes da violência sexual contra mulheres e adolescentes. Brasília: Ministério da Saúde, 1998. Disponível em: https://jornalggn. com.br/sites/default/files/documentos/norma_ tecnica_9nov1998_0.pdf. Acesso em: 9 ago. 2018.

OLIVEIRA, Rayane Noronha. 0 aborto no Brasil: análise das audiências públicas do Senado Federal (2015-2016). 2017. 153f. Dissertação (Mestrado) - Departamento de Sociologia da Universidade de Brasília, maio de 2017. Disponível em: http:// repositorio.unb.br/bitstream/10482/31032/1/2017 RayaneNoronhaOliveira.pdf Acesso em: 11 ago. 2018.

PIMENTEL, Silvia; VILELA, Wilza. Um pouco da história da luta feminista pela descriminalização do aborto no Brasil. Ciência e Cultura, São Paulo, v. 64, n. 2, apr./june 2012. Disponível em: http:// cienciaecultura.bvs.br/pdf/cic/v64n2/a10v64n2.pdf. Acesso em: 11 ago. 2018.
PINTO, C. R. J. Uma história do feminismo no Brasil.

São Paulo: Fundação Perseu Abramo, 2003.

ROCHA, Maria Isabel Baltar da. A questão do aborto no Legislativo brasileiro: uma visão geral dos anos 90 e da década atual. Encontro Nacional de Estudos Populacionais, 16, Anais [...], Caxambu, MG, 29 set./3 out. 2008 .

ROCHA, Maria Isabel Baltar da. A discussão política sobre aborto no Brasil: uma síntese. Revista Brasileira de Estudos de População, Belo Horizonte, v. 23, n. 2, 2006. Disponível em: http:// www.scielo.br/pdf/rbepop/v23n2/a11v23n2.pdf>. Acesso em: 7 ago. 2018.

SANTOS, Chico. Ruth defende projeto sobre aborto. Folha de São Paulo, São Paulo, 2 de outubro de 1997. Disponível em: https://www1.folha.uol.com.br/ fsp/brasil/fc021003.htm. Acesso em: 2 ago. 2018.

SENADO Notícias. ABORTO divide opiniões em debate na Comissão de Direitos Humanos. Ago. 2015. Disponível em https://www12.senado.leg. br/noticias/materias/2015/08/06/aborto-divideopinioes-em-debate-na-comissao-de-direitoshumanos. Acesso em: 7 ago. 2018.

\section{SENADO Federal. Audiências públicas sobre a} temática do aborto. Participação Débora Diniz. 2015. Disponível em: https://www.youtube.com/ watch?v=rpolqxlaFvg. Acesso em 10 ago. 2018.

\section{SENADO Federal. Audiências públicas sobre a} temática do aborto. Participação Padre Paulo Ricardo. Disponível em: https://www.youtube.com/ watch?v=gaaJQVZSGss. Acesso em: 10 ago. 2018.

SILVA, Salete Maria da Silva. A carta que elas escreveram: as mulheres na Constituinte de 1987/88. Instituto Memória. Centro de Estudos da Contemporaneidade, 2016. 
SUPREMO Tribunal Federal. Habeas Corpus 124.306 Rio de Janeiro. Voto-vista do Ministro Luís Roberto Barroso. Disponível em: http://www.stf.jus.br/ arquivo/cms/noticiaNoticiaStf/anexo/HC124306LRB. pdf. Acesso em: 11 ago. 2018

SUWWAN, L. País tem quase 2 abortos ilegais por minuto. Folha de S. Paulo, São Paulo, 10 dez. 2004. Disponível em: http://www1.folha.uol. com.br/fsp/ cotidian/ff1012200406.htm. Acesso em: 30 jul. 2018.

TELES, Maria Amélia de Almeida. Breve história do feminismo no Brasil. São Paulo: Brasiliense, 1999.
TEMPORÃO, José Gomes. Ministro da saúde defende legalização do aborto. globo.com, 28/3/2007. Disponível em: http://g1.globo.com/Noticias/ Brasil/0,,AA1503337-5598,00-MINISTRO+DA+SAU DE+DEFENDE+LEGALIZACAO+DO+ABORTO.html. Acesso em: 2 ago. 2018.

VEJA o que pensam candidatos à Presidência sobre aborto, maconha e religião. Brasília, Rio e São Paulo, Uol, 14/7/2014. Disponível em: https://eleicoes. uol.com.br/2014/noticias/2014/07/14/veja-o-quepensam-candidatos-a-presidencia-sobre-abortomaconha-e-religiao.htm. Acesso em: 2 ago. 2018.
Data da submissão: 19 de Agosto de 2018

Avaliado em: 3 de Setembro de 2018

Avaliado em: 16 de Setembro de 2018

Aceito em: 17 de Setembro de 2018

\begin{abstract}
1 Advogada feminista; Doutora em Estudos Interdisciplinares sobre Mulheres, Gênero e Feminismos; Mestre em Direito; Docente do Departamento de Estudos de Gênero e Feminismo da UFBA; Coordenadora do JUSFEMINA. E-mail: saletemaria@oi.com.br

2 Bacharela em Direito; Doutora e mestre em Ciência Política e em Ciências Sociais; Docente do Departamento de Estudos Gênero e Feminismo da UFBA; Coordenadora do JUSFEMINA. E-mail: wri2sonia@hotmail.com

3 Advogado; Servidor público EPPGG do estado da Bahia; Doutor e mestre em Família na Sociedade Contemporânea; Membro do JUSFEMINA. E-mail: eneziodedeus@gmail.com.

4 Advogado; Doutor e mestre em Direito; Docente titular do Mestrado em Direitos Humanos da UNIT-SE. E-mail: ilzver@gmail.com

5 Pós-doutor pela Pace Universtity/NY; Docente do Programa de Mestrado e Doutorado em Direito- UFBA. Promotor de Justiça em Salvador-BA. E-mail: heron@ufba.br
\end{abstract}


